\title{
ESTETIKA KERAMIK KLASIK DAN KONTEMPORER
}

\author{
Prima Yustana \\ Fakultas Seni Rupa dan Desain, Institut Seni Indonesia Surakarta \\ Email: pyprim@gmail.com
}

\begin{abstract}
AESTHETIC OF CLASSICAL AND CONTEMPORARY CERAMICS
\end{abstract}
\begin{abstract}
The terms classic and contemporary in this study are interpreted as products that still survive to this day in the form of both classic and contemporary ceramic works or ceramic works today. This researh is a qualitative research using the Aesthetic approach, so that several problems will emerge that must be solved by the method, first, what is meant by Classic and Contemporary ceramics, the second How to Aesthetic Classic and Contemporary Ceramics. The third problem is how the visual form of classical and contemporary ceramics that exist today. The beauty of ceramics can be seen from various perspectives, in this research will also be examined through a variety of written data to increase the validity of the data so that it can provide a good conclusion. Ceramic works are works of art that are very rich in technique, so this research also examines how the relationship between formation techniques and the aesthetics of ceramic works.
\end{abstract}

Keywords: Ceramics, Aesthetics, Classic, Contemporary

\section{Latar Belakang}

Indonesia merupakan negara berkembang yang memiliki banyak sekali potensi seni dan budaya, seni merupakan hasil dari sebuah budaya yang dihasilkan oleh manusia. Manusia mempunyai potensi yang sangat luar biasa untuk membuat sebuah benda yang mempunyai nilai fungsi maupun nilai keindahan.

Manusia dan Seni menjadi sebuah satu kesatuan yang utuh yang dapat menghasilkan karya yang sangat beragam jenis maupun wujudnya. Keberagaman merupakan istilah yang muncul dari wujud nyata perbedaan kreatifitasmanusia dalam menciptakan sebuah benda ataupun produk seni.

Manusia mempunyai akal yang sangat berpengaruh terhadap segala perilakunya, manusia yang satu dengan yang lainnya memiliki sifat dan karakter yang berbedabeda. Perilaku dan karakter yang berbeda ini juga akan mempengaruhi setiap kreasi yang dibuatnya. Benda yang dibuat manusia juga akan mempunyai karakter tertentu apabila konsep dan gagasannya muncul dari kemurnian pola pikir pembuatnya. Keramik merupakan sebuah istilah yang muncul dari sebuah pengalaman manusia dalam memenuhi kebutuhan dalam kehidupannya, beberapa versi mengatakan bahwa dahulu kala pembuatan keramik dimulai dari sebuah ketidaksengajaan seseorang yang membakar keranjang yang diliputi tanah liat, setelah dibakar maka tanah liat yang meliputi keranjang tersebut menjadi keras dan membentuk sebuah wadah baru, dari kejadian tersebut maka manusia mulai paham bahwa tanah liat yang dibakar akan menjadi keras dan dapat dibentuk sesuai dengan keinginan pembuatnya.

Fenomena yang ada saat ini, perkembangan keramik sangat luar biasa sekali, beragam jenis ragam produknya, sering dijumpai lewat berbagai acara pameran maupun masih eksis digunakan masyarakat sebagai benda fungsional, eksistensi keramik hingga saat ini sangat menarik untuk dianalisis sebagai sebuah fenomena yang menarik, sebab keramik mempunyai karakter yang unik yang memiliki 
banyak jenis variasi produknya. Setiap produk memiliki latar belakang yang berbeda baik sejarah maupun teknik pembuatannya, hal ini dapat dijadikan sebagai acuan secara teoritis dan praktik untuk pengembangan bermacam produk fungsional maupun hias.

Kontemporer, istilah ini sering bersanding dengan karya seni dalam sebuah tema dalam perhelatan pameran, walaupun bidang lain juga sering menyandingkan dengan subyek bahasan yang berbeda. Dalam buku Diksi Rupa istilah kontemporer dalam seni rupa kontemporer secara umum diartikan seni rupa yang berkembang masa kini, karena kata "kontemporer" itu sendiri berarti masa yang sezaman dengan penulis atau pengamat, atau masa saat ini. Karena istilah ini menunjuk pada sudut waktu,sehingga yang terlihat adalah tren yang terjadi dan banyak mewarnai pada suatu masa atau zaman, jika dikaji lebih luas pada latarbelakang yang muncul dalam seni rupa kontemporer memang sangat beragam, karena belum ada kesepakatan yang baku untuk memberi tanda pada seni rupa kontemporer. ${ }^{1}$ Jadi dalam penelitian ini banyak membahas juga tentang proses bagaimana terjadinya keramik kontemporer yang orang sering melihat di berbagai pameran maupun katalog dengan berbagai macam bentuk dan warnanya.

Klasik merupakan sebuah istilah yang selalu terkait dengan masa lampau, dalam buku Diksi Rupa mempunyai arti memiliki nilai atau mutu yang diakui dan menjadi tolok ukur kesempurnaan yang abadi, di Indonesia yang disebut seni rupa klasik adalah bentuk ekspresi seni yang mencapai puncaknya pada periode kebudayaan Hindu dan Buddha (di Jawa dan Bali) dan Islam (di Sumatra, Jawa, dan Maluku), sebutan klasik juga dapat diterapkan dalam pengertian suatu periode seni dalam gaya tertentu yang mencapai puncaknya. ${ }^{2}$ Sehingga berdasarkan pengertian tersebut maka dalam

1. Mikke Susanto, “Diksi Rupa” DictiArt Laboratory, Yogyakarta, 2018, h. 366

2. Mikke Susanto, 2018, h. 230 penelitian ini juga akan banyak mengulas berbagai produk keramik ataupun sedikit sejarah yang terkait dengan keramik yang terdapat dalam relief baik candi Hindu maupun Buddha serta berbagai keramik peninggalan Islam.

Penjelasan di atas dapat dijadikan pedoman untuk membahas karya-karya keramik yang sangat unik berikut dengan latar belakang kemunculannya. Merujuk dari pendapat Imam Buchori Zainudin bahwa keunikan dalam kriya merupakan faktor penting, keunikan memang relatif, bergantung pada persepsi yang melihatnya. ${ }^{3}$ Keramik juga merupakan salah satu jenis yang unik sebab ada berbagai sisi yang dapat diugkap secara keindahan yang muncul dari proses garapnya, mulai dari teknik penciptaanya maupun proses kreatif yang ada pada setiap perwujudan karya.

Keramik kontemporer tidak terbatasi hanya pada karya seniman saja akan tetapi hasil industri keramik saat ini juga akan dibahas dalam penelitian ini, Agus Sachari memberikan sebuah keterangan bahwa industri kecil akar perkembangan industrialisasi di wilayah Indonesia, terutama industri kecil, tidaklah terpisah dari budaya keterampilan yang telah diwariskan nenek moyang bangsa Indonesia secara turun temurun. Jika sebagian besar wilayah Nusantara yang subur ditumbuhi hutan, dan kaya akan lempung dan bebatuan, maka keterampilan tangan yang pertama-tama dimiliki nenek moyang yang hidup di wilayah ini adalah keterampilan membuat perabot dari kayu, tembikar dan batu. Artifak-artifak yang terbuat dari kayu memang pendek umurnya, sehingga karya-karya adiluhung yang diciptakan cenderung punah. Sedangkan artifak dari tembikar, sebagian masih tersisa dan artifak yang terbuat dari batu memiliki usia yang lebih lama, seperti halnya candi, nisan, prasasti,

3. Imam Buchori Zainudin, Kriya Tradisi Dalam Wacana Pendidikan Tinggi Menghadapi Budaya Global, Makalah seminar nasional "Kriya Indonesia Dan Tantangan Era Globalisasi Abad 21" 29 September 1999. h. 8 . 
ataupun relief. Tradisi kerajinan tangan yang telah dirintis nenek moyang bangsa Indonesia merupakan landasan ketrampilan turun temurun dengan hasil yang berkualitas tinggi. ${ }^{4}$ Artefak menjadi objek yang dapat menjelaskan dengan jelas apa yang terjadi pada masa lampau terkait produk keramik masa lampau dan masa kini.

\section{B. Rumusan Masalah}

Rumusan masalah dalam penelitian ini, yaitu :

1. Apakah yang dimaksud dengan keramik Klasik dan Kontemporer?

2. Bagaimana Estetika Keramik Klasik dan Kontemporer?

3. Bagaimana bentuk visual keramik klasik dan kontemporer yang ada pada saat ini?

\section{Tinjauan Pustaka}

Ada beberapa literatur yang dipergunakan peneliti sebagai sumber kajian untuk dijadikan landasan teori yang relevan dengan penelitian ini, antara lain :

Arkeologi Budaya Indonesia ditulis oleh Jakob Sumardjo, buku ini menerangkan tetang kesenian dan gambar prasejarah bangsa Indonesia yang dibahas berlatar budaya dan disertai dengan keterangan gambar artefak, tulisan ini sangat bermanfaat untuk mengulas bagaimana awal mula munculnya keramik di beberapa wilayah di Indonesia.

Kamus Besar Bahasa Indonesia, Edisi Ketiga, disusun oleh Tim Penyusun Balai Pustaka. Buku ini merupakan sebuah buku yang memuat khasanah perbendaharaan kata suatu bahasa yang menampung perkembangan kosa kata dan istilah baru, baik yang berupa kata dasar maupun kata atau istilah turunan dari bahasa asing yang terjadi di masyarakat sesuai dengan perubahan dan kemajuan zaman yang pada gilirannya berpengaruh pada tuntutan

4Agus Sachari, Budaya Visual Indonesia, Penerbit Erlangga, Jakarta, 2007, h. 103. masyarakat terhadap bahasa Indonesia yang salah satunya sebagai sarana komunikasi dalam bidang kehidupan. Buku ini dijadikan sebagai salah satu acuan dasar peneliti menerangkan istilah yang perlu dijelaskan lebih detail.

www.studiokeramik.com. Website ini, banyak memberikan informasi-informasi penting dalam beberapa bidang yang berkaitan dengan aktivitas berkeramik. Website ini sangat membantu peneliti dalam mencari informasi secara tertulis untuk mencoba di-cross cek ulang dan mengajukan pertanyaan-pertanyaan seputar objek kajian penelitian ketika berada di lokasi penelitian.

Pengetahuan Keramik. Ditulis oleh Ambar Astuti. Buku ini berupaya mengungkapkan berbagai macam keterangan tentang keramik mulai dari bahan hingga proses pembentukan hingga kandungan kimia yang terdapat dalam ilmu keramik. Buku ini peneliti rujuk untuk menjelaskan kandungan kimia dalam keramik dan tanah liat agar bisa di dapatkan sebuah keterangan yang detail dalam menjelaskan kendala-kendala muncul dalam penelitian tersebut.

Industri Keramik. Ditulis oleh R.A. Razak. Buku ini menguraikan tentang berbagai permasalahan dan solusi yang terdapat di dalam industri keramik secara khusus, isinya akan membimbing pembaca untuk melaksanakan langkah-langkah yang tepat untuk membangun sebuah idustri keramik yang baik. Buku ini membantu penulis untuk dapat memahami bagaimana pekerjaan-pekerjaan dan berbagai permasalahan yang ada pada industri keramik, sehingga dapat dijadikan pijakan untuk menentukan langkah apa saja yang perlu dipersiapkan apabila seorang pengrajin dalam mengelola sebuah industri keramik.

Estetika, oleh Dharsono. Buku ini berisikan tentang teori seni rupa dan pentingnya berbagai unsur yang mempengaruhi karya seni, termasuk di dalamnya mengulas tentang teori kretivitas. Buku ini diacu penulis sebagai landasan untuk menganalisis berbagai permasalahn seni rupa yang berkaitan dengan 
bentuk, teknik dan pewarnaan.

Seni Kriya Dan Pelestariannya Di Indonesia, oleh Hedi Sri Ahimsa Putra. Sebuah makalah yang sangat menarik dipaparkan oleh seorang antopolog budaya dari UGM dalam seminar. Makalah ini dijadikan pijakan peneliti atas keadaan perkembangan seni keramik yang masih banyak kekurangan dan perlu adanya pengembangan terutama dari faktor variasi warna dan bentuknya.

Budaya Visual Indonesia. Ditulis oleh Agus Sachari. Buku ini berisi tentang pola-pola pikir desain dan pengembangannya. Buku ini diacu oleh penulis agar dapat memprediksikan pengembangan apa yang bisa ditempuh setelah menguasai teknik pembentukan dengan tepat di masa yang akan dating dengan mempertimbangkan perkembangan desain yang dipaparkan dalam buku tersebut.

Studies On Ceramics. Editor kumpulan makalah ini adalah Satyawati Sulaiman . Buku yang berupa kumpulan makalah ini mencoba menerangkan keberagaman temuan keramik mulai dari prasejarah hingga saat ini. Kumpulan makalah ini membantu peneliti untuk mengetahui dan mendapatkan keterangan tentang kualitas keramik pada masa prasejarah dan perkembangannya di berbagai daerah di Indonesia maupun di luar Indonesia.

Kamus Keramik. Ditulis oleh Brian Alexander. Secara garis besar buku ini tidak banyak mengungkapkan tentang teori-teori tetapi buku ini berupa kamus dan disusun menurut abjad. Buku ini sangat membantu peneliti untuk mengetahui secara detail apa maksud dari islilah-istilah dalam keramik.

Chinese And Japenese Work Of Art. Buku ini banyak memberikan contoh-contoh warna keramik karya-karya dari cina dan jepang. Peneliti perlu melihat

buku ini sebagai acuan untuk membandingkan produk yang dihasilkan apakah dapat menyerupai atau dapat menyamai produk keramik dari negara-negara pengahasil keramik tersebut.

Bahasa Rupa. Buku ini banyak mengulas tentang perbandingan antara bahasa rupa dan bahasa kata, bahasa rupa cenderung dipandang sebagai bahasa komunikasi yang berupa gerak dari gambar mengandung makna-makna tertertu. Dalam bahasa rupa tetap disinggung peranan tentang warna. Buku ini peneliti baca sebagai acuan berfikir bagaimana unsur-unsur dalam seni rupa tersebut dapat mempengaruhi atau berkomunikasi dengan penikmatnya.

Glazes For The Craft Potter, Buku ini banyak memberikan keterangan tentang teknik pengglasiran dalam keramik baik dari kandungan kimia, komposisi, dan yang paling penting tentang pewarnaan glasir diulas secara detail. Buku ini diacu oleh peneliti sebagai pegangan dalam menganalisis kemungkinan finishing glasir dapat diterapkan.

Ettore Sottsass. Ceramics, Buku ini banyak memuat tentang karya-karya keramik yang berglasir dengan glasir yang bagus dan maksimal. Buku ini digunakan oleh peneliti sebagai acuan dalam mengembangkan produk keramik Bayat dengan karya keramik yang berglasir untuk menganalisis bagaimana keunggulan masing-masing jenisnya.

Pottery and Ceramics. Buku ini berisi tentang keramik dari berbagai negara dengan segala visualisasi karakter glasir yang muncul, glasir yang muncul tersebut mempunyai perbedaan perbedaan disebabkan pembuatanya juga berasal dari berbagai negara. Buku ini diacu oleh peneliti untuk mengetahui karakter glasir dari banyak negara yang telah menghasilkan glasir tersebut sehingga peneliti mengetahui contoh-contoh finishing glasir dari beberapa negara sebagai acuan pengembangan kombinasi finishing keramik.

\section{Road Map}

Coservasi Lapangan

Kajian Pustaka dengan pendekatan multidisiplin

Analisis Data

Kesimpulan 


\section{E. Metode Penelitian}

Dalam rangka menjawab rumusan masalah yang diangkat dan penggalian informasi sebanyak-banyaknya, penelitian ini menggunakan metode penelitian kualitatif Lexy J. Moleong. Pemaparan dan penggambaran penelitian ini meliputi aspek-aspek sebagai berikut:

1. Pada awalnya akan mencoba mengetahui secara alamiah sejarah keramik baik yang klasik maupun kontemporer, apakah ada fenomena yang berkait dengan produk keramik yang dihasilkan pada batasan waktu tersebut.

2. Identifikasi visual produk dan berbagai permasalahannya.

3. Pembedahan permasalahan data dengan menggunakan multidisiplin ilmu baik sejarah, budaya dan khususnya ilmu seni rupa.

Lokasi penelitian tersebar di wilayah Jogja dan Jateng meliputi beberapa perpustakaan yang ada di wilayah tersebut, seperti perpustakaan ISI Surakarta, UGM, ISI Yogyakarta, Perpustakaan Museum maupun Balai cagar budaya dan tidak lupa perpustakaan digital, ditambah dengan analisis pustaka buku koleksi penulis.

\section{Bidang Penelitian}

Dalam penelitian ini, perlu ditentukan ruang lingkup bidang kajiannya. Hal ini penting dilakukan untuk mencapai arah penelitian secara tepat, sehingga dapat mempertajam kajian penelitian.

Penelitian yang akan dilakukan merupakan kajian terfokus pada Kajian pustaka dengan mengambil kasus bermacam produk keramik klasik dan kontemporer dengan pendekatan multidisiplin termasuk estetika. Harapan peneliti akan mendapatkan kejelasan dan mendapat data-data valid untuk mendukung karya ilmiah yang lebih baik, teriring harapan pula sebagai data awal persiapan untuk studi dalam level yang lebih tinggi.

\section{Sumber Pengumpulan Data}

Sumber-sumber informasi dan data-data penting yang masih relevan dengan penelitian ini dikumpulkan menggunakan teknik Kajian Pustaka.

\subsection{Dokumentasi dan Pencatatan}

Teknik ini dilakukan untuk mencatat dan mendokumentasikan semua data-data yang diperoleh melalui penggunaan metode penelitian ini baik secara laporan tertulis, image gambar/ visual.

Alat yang digunakan untuk mendukung teknik ini, selain alat tulis manual juga menggunakan alat elektronik berupa kamera foto digital dan laptop.

\subsection{Analisis Data}

Data yang telah dikumpulkan dalam penelitian ini akan diolah, dianalisis, dan dideskripsikan dalam bentuk uraian dengan memaparkan dan menggambarkan data penelitian sebagaimana keadaan sebenarnya baik secara tertulis maupun dengan dukungan gambar. Teknis analisis data yang digunakan adalah teknik deskriptif kualitatif. Teknik ini akan memberikan gambaran yang tepat dari sesuatu permasalahan yang ditemukan.

Pengolahan data akan selalu mempertimbangkan:

1. Hal apa saja yang terkait dengan keramik klasik maupun kontemporer.

2. Kajian estetika menjadi point penting terkait karakteristik keindahan keramik Klasik dan Kontemporer.

\section{ESTETIKA KERAMIK KLASIK DAN KONTEMPORER}

\section{ESTETIKA}

\section{Pengertian Estetika}

Menurut Kamus Besar Bahasa Indonesia, estetika memiliki pengertian cabang filsafat yang menelaah dan membahas tentang seni dan keindahan serta tanggapan manusia 
terhadapnya. ${ }^{5}$ Estetika menurut Mieke Susanto dalam bukunya Diksi Rupa berarti:

1. Mengenai keindahan; tentang apresiasi keindahan;

2. Mempunyai penilaian terhadap keindahan (=>Indah);

3. Hal yang terkait dengan keindahan dan rasa.

Kata estetika diserap dari aesthetics (Ing.), berasal dari bahasa Yunani "aisthanomai" yang berarti " hal yang ditangkap lewat indrawi dan bermuara pada perasaan (things perceived by the sense)" sebagai oposisi dari "hal yang dipahami menggunakan akal (things known by the mind)". Kata "aisthanomai" memiliki akar kata "aesthesis", sepadan dengan kata perasaan atau persepsi. Istilah ini adalah cabang filsafat yang menelaah dan membahas tentang seni dan keindahan serta tanggapan manusia terhadapnya. Estetika dikenal memiliki dua pendekatan: pertama langsung meneliti dalam objek-objek atau benda-benda atau alam indah serta karya seni, kedua menyoroti situasi kontemplasi rasa indah yang sedang dialami si subjek, yang kemudian melahirkan berbagai pengertian yang sangat bervariatif, dalam arti memiliki banyak perspektif pendekatan, sehingga persoalan estetika bergantung pada situasi, kondisi dan posisi dimana ia berada. Istilah ini pertama didengungkan oleh Alexander Baumgarten dan digunakan juga oleh Imanuel Kant dalam Critique of Judgment. ${ }^{6}$

Beberapa pengertian estetika dan lingkupnya dapat dicermati di bawah ini : Estetika adalah segala sesuatu dan kajian terhadap hal-hal nyang berkaitan dengan kegiatan seni menurut Kattsoff, dalam Element of Philosophy, 1953. Estetika merupakan suatu telaah yang berkaitan dengan penciptaan, apresiasi, dan kritik terhadap karya seni dalam konteks keterkaitan seni dengan kegiatan manusia dan peranan seni dalam perubahan dunia menurut van Mater Ames, dalam Colliers

5 Kamus KBBI versi aplikasi android

6 Mieke Susanto, Diksi Rupa, Dictiart Laboratory, Yogyakarta, 2018, halaman 127
Encyclopedia, vol. 1. Estetika merupakan kajian filsafat keindahan dan juga keburukan menurut Jerome Stolnitz, dalam Encyclopedia of Philosophy, vol. 1. Estetika adalah suatu ilmu yang mempelajari segala sesuatu yang berkaitan dengan keindahan, mempelajari semua aspek yang disebut keindahan menurut AA Djelantik dalam Estetika Suatu Pengantar, 1999. Estetika adalah segala sesuatu yang berhubungan dengan sifat dasar nilai-nilai non moral suatu karya seni menurut William Haverson, dalam Estetika Terapan, 1989.

Estetika merupakan cabang filsafat yang berkaitan dengan proses penciptaan karya estetis menurut John Hosper, dalam Estetika Terapan, 1989. Estetika adalah filsafat yang membahas esensi dari totalitas kehidupan estetika dan artistik yang sejalan dengan zaman menurut Agus Sachari, dalam Estetika Terapan, 1989.

Estetika mempersoalkan hakikat keindahan alam dan karya seni, sedangkan filsafat seni mempersoalkan hanya karya seni, atau artifak yang disebut seni menurut Jakob Sumardjo dalam Filsafat Seni, $2000 .^{7}$

Dari beberapa pendapat tersebut dapat disarikan bahwa permasalahan estetika dapat dipastikan terkait dengan sebuah karya seni, terlepas karya tersebut indah atau tidak indah hal tersebut merupakan sebuah ekspresi yang muncul dari seniman dan kadang tanggapan dari apresian akan terjadi perbedaan tanggapan satu dengan yang lainnya dan estetika selalu membahas elemen-elemen keindahan dalam seni.

\section{Estetika Timur}

Dalam kajian geo-budaya, Indonesia kerap dikategorikan sebagai Negara Timur bersama dengan sebagian besar wilayah Asia lainnya. Karateristik nilai estetika timur dapat diuraikan sebagai berikut, bahwa terdapat

7 Agus Sachari, Estetika Makna, Simbol dan Daya, Penerbit ITB, 2002, halaman 3 
kecendrungan pendapat bahwa dunia merasa "Timur" lebih menekankan pada aspek intuisi daripada akal. Pada masyarakat "Timur", pusat kepribadian seseorang bukanlah pada daya intelektualnya, melainkan ada dalam hati, yang mempersatukan akal budi, intuisi, kecerdasan, dan perasaan. Masyarakat Timur menghayati hidup dalam apa adanya, bukan semata akali. "Hati" atau "rasa" dinilai sebagai pengganti logika kaku yang serba terbatas menghadapi kebenaran hidup. Manusia Timur memiliki suatu bentuk pemikiran berdasarkan intuisi, yang akrab, hangat, personal, dan biasanya memiliki kedekatan dengan realitas yang hakiki. ${ }^{8}$

Berlandaskan pendapat tersebut estetika timur merupakan sebuah pemahaman estetik yang lebih jauh tidak hanya sebatas akal saja tetapi melibatkan berbagai hal yang sangat personal dalam diri manusia yang berkaitan dengan hakikat kehidupan yang hakiki, rasa menjadi point penting dalam estetika timur yang menjadikan semua berada di atas logika.

Ada perbedaan yang dalam antara sistem-sistem filsafat Barat dengan ungkapanungkapan renungan filsafat Jawa (nusantara) yang bersifat fragmentaris dan kurang nampak adanya hubungan yang jelas. Terdapat perbedaan sebagian filsafat barat dan timur, para ahli filsafat timur mengatakan : "Bukan menciptakan filsafat untuk filsafat sendiri. Pengetahuan senantiasa hanya merupakan sarana untuk mencapai kasampurnan" Suatu langkah kejalan menuju kalepasan (verlossing) atau malahan mencapainya; yaitu satu-satunya jalan bagi manusia untuk sampai kepada tujuan akhirnya. Berlainan dengan kebanyakan pemikiran barat, disini tidak kita dapatkan pertentangan antara filsafat dengan pengetahuan tentang Tuhan. Justru didapatkan pada filsafat nusantara (Jawa) bahwa kearifan tertinggi, yang merupakan puncak filsafat filsafat adalah pengetahuan tentang Tuhan, tentang Yang Mutlak dan hubunganNya dengan manusia.

$$
\text { Kalau filsafat barat selalu }
$$

\footnotetext{
8 Agus Sachari, 2002, halaman 9
}

mempertanyakan tentang hidup ini secara logika maka filsafat Nusantara selalu mempertanyakan tentang perjalanan hidup dalam mencapai kasampurnan. Bilamana kita pakai bahasa Jawa sendiri, maka filsafat berarti: "ngudi kasampurnan" (berusaha untuk mencapai kasampurnan sejati). Sebaiknya philosopia Yunani dibaca dengan bahasa Jawa menjadi: "ngudi kawicaksanan" (berusaha untuk memperoleh kepandaian/kepinteran). ${ }^{9}$

Hal tersebut di atas lebih meyakinkan bahwa kehidupan dan perilaku seni budaya timur lebih menuju pada kesempurnaan hidup dan hubungan manusia dengan tuhannya, maka dengan demikian karya seni yang lahir dalam konteks seni yang ada di wilayah timur, maka akan dengan baik dapat dijelaskan dengan pendekatan-pendekatan reliji yang menjadi kepercayaan masyarakat dalam komunitasnya masing-masing.

\section{Estetika Barat}

Estetika Barat hakikatnya telah terbentuk sejak kebudayaan Yunani diakui sebagai peradaban manusia yang amat berpengaruh terhadap lahirnya kesadaran-kesadaran akan keindahan.

Secara historis, penyadaran akan keindahan dalam peradaban Barat dimulai dari zaman Yunani, yang diawali oleh dialog antara Socrates dan Hippias tentang pelbagai pertanyaan keindahan. Dalam proses dialog tersebut, Socrates selalu menggiring bahwa keindahan itu relatif terhadap yang lain, dan keindahan yang mutlak adalah tetap buatan yang Maha Kuasa. Socrates juga menyatakan bahwa dibalik semua benda yang indah, terdapat keindahan terbangun oleh dirinya sendiri. Itulah keindahan yang benar-benar indah dalam arti sesungguhnya.

Selain itu Plato, sebagai murid Socrates mengungkapkan bahwa keindahan suatu obyek disadari oleh manusia melalui adanya keindahan

9. Dharsono (Sony Kartika), Estetika, Rekayasa Sains, 2007, halaman 130 
"awal" (keindahan yang mula-mula). Kesadaran akan keindahan "awal" inilah yang membangun suatu benda menjadi indah. Plato berpendapat bahwa keindahan dapat diperoleh melalui "cinta". "Cinta" adalah yang membangun keyakinan adanya keindahan yang ideal.

Penggagas estetika Yunani lainnya adalah Aristoteles, yang beranggapan bahwa keindahan suatu benda hakikatnya tercermin dari keteraturan, kerapihan, keterukuran, dan keagungan. Keindahan yang dicapai adalah keserasian bentuk (wujud) yang setinggi-tingginya. Bagi aristoteles, karya seni dinilai memiliki nilai keindahan yang lebih dibandingkan keindahan yang terjadi di alam, meskipun tidak tertutup terdapat karya seni yang lebih rendah daripada alam. Seni adalah karya cipta yang dibimbing oleh pikiran dalam arti yang sebenarnya. ${ }^{10}$

\section{DEFINISI KLASIK DAN KONTEMPORER}

\section{Pengertian Klasik}

Menurut KBBI kata klasik mempunyai nilai atau mutu yang diakui dan menjadi tolok ukur kesempurnaan yang abadi;tertinggi. ${ }^{11}$ Dalam Diksi Rupa klasik memiliki arti 1. Memiliki nilai atau mutu yang diakui dan menjadi tolo ukur kesempurnaan yang abadi; 2 . Kata sifat "klasik" berasal dari classicus (Lat.) atau classical (Ing.) berarti "warga Negara Roma kelas satu"; 3. Sebutan klasik berarti gaya seni dan cara berfikir, yang secara khusus lebih merujuk pada perkembangan sejarah kebudayaan Yunani antara 400 s.d. 350 SM. dan dilanjutkan pada sejarah kebudayaan Romawi tahun 50 SM. s.d. 50 M. Ciri-ciri kebudayaan klasik (termasuk seni rupanya) meliputi: 1. rasional, 2. logis, 3. keseimbangan, 4. keindahan ideal, 5 . bentuk sempurna, dan 6. kejelasan. Di Eropa Barat pada zaman $=>$ Renaissance abad ke-15, gaya klasik dikembangkan menjadi prinsip-prinsip keindahan dan kebenaran universal. Segala macam seni diukur dan disertakan dengan karya-karya klasik Yunani dan Romawi; 4. Sedangkan di Indonesia, yang disebut dengan seni rupa Klasik adalah bentuk ekspresi seni yang mencapai puncaknya pada periode kebudayaan Hindu dan Buddha (di Jawa dan Bali) dan Islam (di Sumatra, Jawa, Maluku). 5. Sebutan klasik juga dapat diterapkan dalam pengertian suatu periode seni dalam gaya tertentu yang mencapai puncaknya. Salah satu contoh adalah sebutan Seni Rupa Modern Klasik (Classical Modernism) digunakan oleh Volkmar Essers, ketika terjadi ketegangan umum dengan adanya dikotomi pemikiran dalam ekspresi seni rupa yang figuratif dengan non-figuratif, yang realistik dengan abstrak. ${ }^{12}$

Berdasar ilmu di atas maka klasik dalam seni rupa dapat ditentukan dengan melihat bentuk ekspresi seni yang mencapai puncaknya pada periode kebudayaan Hindu dan Buddha (di Jawa dan Bali) dan Islam (di Sumatra, Jawa, Maluku). Demikian juga apabila melihat karya keramik, tentunya berbagai macam bentuk yang ada ketika artefaknya sesuai dengan kriteria tersebut maka dapat dikatakan itu adalah benda keramik klasik.

\section{Pengertian Kontemporer}

Menurut KBBI : pada waktu yang sama; sewaktu; pada masa kini. ${ }^{13}$ Seni rupa kontemporer secara umum diartikan seni rupa yang berkembang masa kini, karena kata "kontemporer" itu sendiri berarti masa yang sezaman dengan penulis atau pengamat atau saat ini. Istilah ini tidak merujuk pada satu karakter, indentitas atau gaya visual tertentu. Karena istilah ini menunjuk pada sudut waktu, sehingga yang terlihat adalah tren yang terjadi dan banyak mewarnai pada suatu masa atau zaman. Jika dikaji lebih luas pada latar belakang yang muncul dalam seni rupa kontemporer
10. Agus Sachari, 2002, halaman 4-5
11. KBBI Aplikasi Android
12. Agus Sachari, 2002, halaman 230

13. KBBI Aplikasi Android 
memang sangat beragam, karenanya belum ada kesepakatan yang baku untuk memberi tanda pada seni rupa modern. Di Barat, seni rupa kontemporer berkembang sejak tahun 1970, bersamaan dengan terjadinya krisis modernism serta bergulirnya wacana $=>$ pascamodernisme. Apabila seni rupa modern sebagai pengagungan seni rupa barat, mengidentikkan prinsip estetika seni rupa dengan menggunakan bendera universalisme, seni rupa kontemporer (secara khusus dalam hal ini pascamodernism) mengakui adanya pluralism. Seni rupa kontemporer berorientasi bebas, tidak menghiraukan batasanbatasan kaku seni rupa yang oleh sementara pihak dianggap baku. Ada yang menganggap seni rupa kontemporer dari sudut teknis, seperti munculnya seni instalasi (yang bersifat instalatif, $=>$ multimedia, $=>$ site specific installation), menguatnya seni lokal (indigenous art), sebagai jawaban atas masalah-masalah yang muncul dalam praktik dan perilaku artistik yang menyimpang dari konvensi sebelumnya (=>Modernisme), ada pula yang menganggap menguatnya pengaruh ideologi postmodern (pascamodernisme) dan post-colonialism dewasa ini, sampai hanya dianggap sebagai pergantian istilah semata dari kata "modern" pada praktik artistik yang sama. "Gerakan" seni rupa kontemporer di Barat memiliki ciriciri mirip "gerakan" postmodernisme, seperti penentangan, penghancuran, yaitu adanya trentren baru yang mencuat mulai dari awal tahuntahun 1970an hingga kini di Barat, seperti isuisu tentang budaya plural (seni tradisi, atau seni lokal/ kedaerahan/ indigenous), diskriminasi gender, dan rasialisme. Pemikiran seni rupa kontemporer agaknya bukan hanya berkait dengan persoalan estetika karya, namun juga pengaruh dan isu politik budaya. Seperti kata Hals Belting yang membedakan istilah "seni rupa dunia (world art)" dan "seni rupa global (global art)". Baginya seni rupa dunia mencerminkan pemahaman-pemahaman Modernisme yang hegemonik dan memperlihatkan sikap-sikap colonial. Sementara itu seni rupa global adalah seni rupa kontemporer yang meluas ke seluruh dunia dalam perkembangan sekarang.
Globalisme bagi Hans Belting, justru merupakan anti-thesis universalisme. ${ }^{14}$

Jadi seni kontemporer adalah seni yang dibuat pada masa kini sehingga segala macam karya seni rupa baik keramik atau bukan maka termasuk dalam klasifikasi seni kontemporer, akan tetapi dalam beberapa pendapat di atas terdapat pengertian bahwa seni kontemporer mulai muncul pada tahun 70 an. Jadi apabila ada acuan angka tahun yang jelas maka seni kontemporer akan mudah diidentifikasi dengan melihat dari angka tahun kapan benda seni rupa tersebut dibuat apakah dibawah tahun 70an atau di atas tahun 70an jika masuk dalam lingkup tahun di atas tahun 70an maka dapat disebut sebagai produk seni kontemporer.

\section{KERAMIK}

\section{Pengertian Keramik dan Sejarah Singkatnya}

Dalam mempelajari sebuah sejarah yang terkait karya seni keramik akan sangat dekat dengan ilmu arkeologi, jadi perlu dipelajari juga data-data terkait artefak keramik dan bagaimana perlakuan dalam mempelajari sebuah artefak dan berbagai kaitannya terhadap kehidupan masa lalu yang melingkupinya. Data dalam arkeologi dikategorikan dalam tiga jenis, yaitu Artefak, Fitur, dan Situs. Artefak adalah benda buatan manusia yang dapat dipindahkan tanpa merusaknya, seperti tembikar, arca, anak panah dan manik-manik. Artefak adalah objek alamiah yang mempunyai hubungan dengan data ekologis lainya pada saat ditemukan, artefak dapat memberikan gambaran mengenai cara manusia berinteraksi dengan lingkungannya. Fitur merupakan peninggalan berupa bekas pemukiman seperti rumah, makam, saluran irigasi dan bangunan besar yang susah dipindahkan, sedangkan Situs adalah sebidang tanah yang di dalamnya mengandung benda-benda arkeologi. ${ }^{15}$

14. Mieke Susanto, 2017, halaman 366

15. M. Yusuf zulfikar, Arkeologi, PT. Remaja Rosdakarya, Bandung, 2011, halaman 3-4 
Keramik merupakan istilah yang menjelaskan tentang sebuah produk yang berbahan dasar tanah liat kemudian dibentuk dengan teknik tertentu sehingga terciptalah benda sesuai dengan keinginan orang yang membentuknya. Benda yang terbuat dari tanah liat ini akan disebut keramik setelah melewati proses pembakaran dengan suhu tinggi yang akan memberikan kematangan pada benda keramik tersebut. Penjelasan tersebut sependapat dengan Ambar Astuti bahwa, keramik merupakan salah satu kerajinan yang paling tua, benda-benda ini dibuat oleh orang-orang Mesir di tepi sungai Nil. Munculnya keramik selama berabad-abad dapat dibuktikan melalui artefak yang diciptakan oleh bangsa-bangsa yang ada di belahan dunia, terutama adalah bangsa Yunani, bangsa Romawi, bangsa Cina pada zaman dinasti Tang dan Sung, bangsa Korea dan juga bangsa Indian Amerika. ${ }^{16}$



Gambar 1. Keramik dari Dynasti Sung, Repro:

Prima Yustana, dari Dictionary of Ceramics Thames \& Hudson, Ltd. London, 2000, halaman 77

Asal kata keramik berasal dari bahasa Yunani "Keramos" yang berarti periuk atau belanga yang dibuat dari tanah. Sedangkan yang dimaksud dengan barang/bahan keramik ialah: semua barang /bahan yang dibuat dari bahanbahan tanah/bahan silikat dan yang proses pembuatannya melalui pembakaran pada suhu tinggi. ${ }^{17}$ Sebagai awal pijakan proses

16. Ambar Astuti, Pengetahuan Keramik, Gadjah Mada Universty Press, Yogyakarta, 1997, halaman 1

17 Ambar Astuti, 1997. halaman 1 analisis terhadap sejarah keberadaan keramik di Indonesia sangat perlu dipahami terlebih dahulu mulai dari pengertian keramik itu sendiri, sehingga ke depan dalam melakukan pembahasan terkait benda keramik akan dapat terklasifikasi dengan jelas terhadap benda yang dimaksud.

Pada zaman dinasti Han yaitu pada abad VIII sampai dinasti $\mathrm{T}^{\mathrm{ee}}$ ang pada abad $\mathrm{X}$, keramik di Tiongkok berkembang dengan pesat. Pada zaman dinasti $\mathrm{T}^{\mathrm{ee}}$ ang, yaitu antara abad VII-X, pemerintah sampai maju disegala bidang. Terutama dibidang kebudayaan dan indutri keramik, yang pada waktu itu menjadi kebanggaan negeri Tiongkok. Pada waktu itu orang-orang Tiong Hoa banyak meniru kebudayaan dari Asia Barat, Persia, Hindustan dan lain-lain. Motif-motif dan corak dari negaranegara tersebut terdapat dalam dekorasi-dekorasi barang-barang keramik. Pada abad IX banyak sekali dibuat piring-piring.18 Berikut beberapa gambaran tentang bentuk-bentuk benda keramik yang berkembang pada masa lampau.

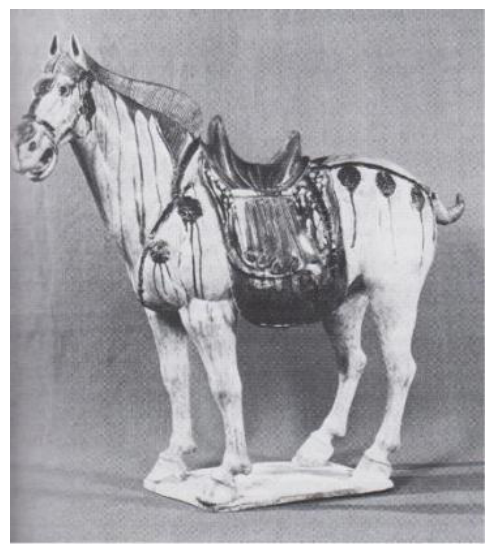

Gambar 2. Patung kuda berglasir masa Dynati Teeang (618-906) koleksi Museum Victoria and Foto: Repro Prima Yustana dalam Dictionary of Ceramics Thames \& Hudson, Ltd. London, 2000, halaman 153

18. R.A.Razak, Industri Keramik, PN Balai Pustaka, Media Wiyata, Semarang, 1992, halaman 6 




Pada abad X dalam dinasti Song dibuat barang-barang porselin yang halus, putih murni dan biru-putih, yang masih digemari orang sampai saat ini. Pada abad XVII barang-barang keramik berkembang dengan sangat pesat, baik kwantum maupun mutunya, sehingga pada zaman dinasti Ming banyak sekali barang-barang tersebut terutama porselin biru-putih diekspor ke negara-negara Eropa dan Asia. Pada zaman itulah banyak Negara-negara Eropa dan Asia meniru membuat barang-barang porselin. Pada abad itulah misalnya Keramos dari Yunani mulai membuat barang-barang keramik, sehingga nama keramik sejak abad itu dikenal sampai sekarang. Demikian juga Jepang pada abad XVII mulai membuat barang-barang keramik. Mereka belajar langsung dari orang-orang Tiongkok. Kemudian muncullah nama "Satsuma" yang tersohor pada abad XVIII sampai abad XX dan nama "Sino Yapanico" untuk barangbarang keramik biru-putih yang mereka tiru dari orang-orang Tiongkok. Barang-barang keramik yang terkenal pada pertengahan abad XVII adalah barang-barang keramik keluaran Kutani dan Imari. Imari mendapat nama baik karena piring-piringnya dan tempat-tempat air yang mempunyai bentuk seperti kendi. Barangbarang porselen keluaran Imari sangat digemari, yang kebanyakan dibuat sesudah abad XVII. ${ }^{19}$

Dalam perlombaan antara Negaranegara yang telah maju, Jepanglah sekarang yang mewakili Asia, karena sudah jauh lebih maju teknologinya daripada Tiongkok sendiri. Di Indonesia pembuatan barang-barang keramik secara sungguh-sungguh baru mulai pada tahun 1956. Pada tahun tersebut, pemerintah mulai turun tangan dengan mendirikan pabrikpabrik keramik yang agak besar, yaitu di Tanjungpandan, Plered, Purwokerto (Kalibagor), Mayong, Malang, dan Tulungagung. ${ }^{20}$

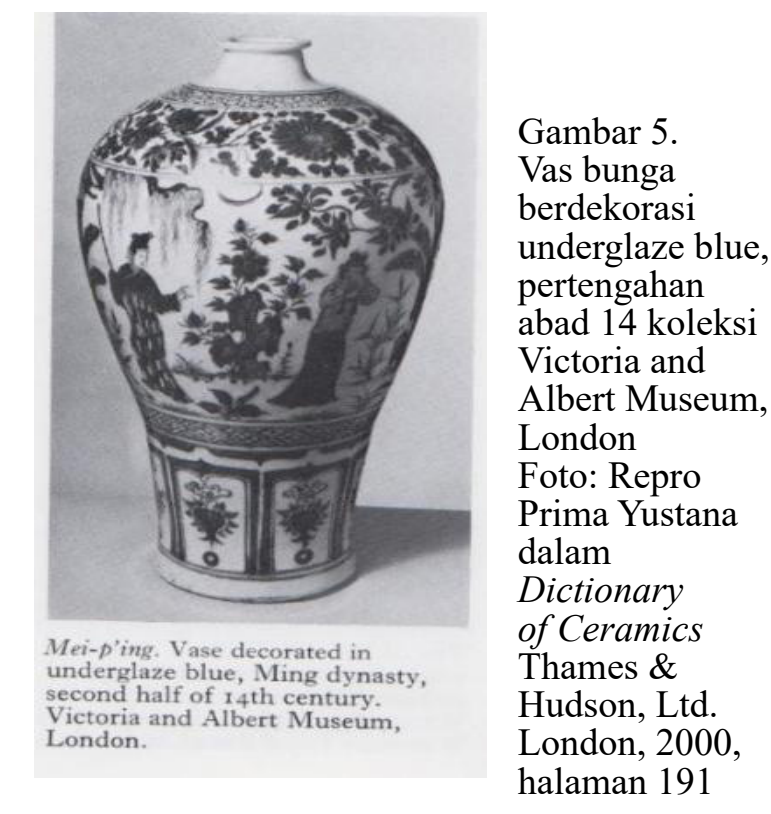

19 R.A. Razak, 1981, halaman 7 20 R.A. Razak, 1981, halaman 7 


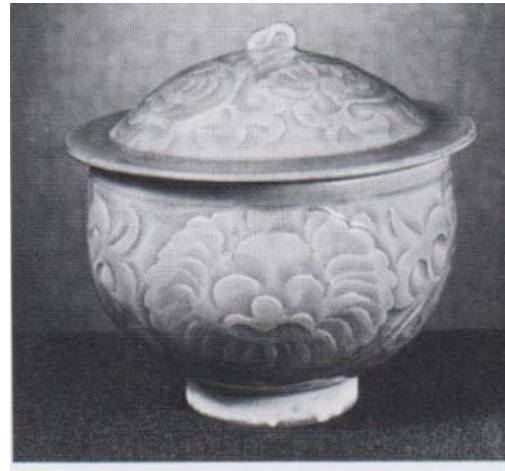

Potiche. Northern celadon, with carved decoration, Sung dynasty (960-1280). Victoria and Albert Museum, London.

\section{Gambar \\ 6. Wadah bertutup dengan finishing celadon dengan} dekorasi ukir masa Dynasti Sung, Koleksi Victoria and Albert

Museum, London Foto: Repro Prima Yustana dalam Dictionary of Ceramics, Thames \& Hudson, Ltd. London, 2000, halaman 231

Gambaran keramik di wilayah Nusantara mempunyai perjalanan tersendiri dimulai dari kebiasaan membuat benda dari tanah liat untuk keperluan hidup sehari-hari adalah tradisi dalam masyarakat petani. Tradisi ini ruparupanya hidup kembali pada zaman Majapahit yang menghasilkan benda-benda gerabah atau terakota seperti periuk, belanga, kendi, jambangan termasuk juga arca-arca berukuran kecil. Dari benda-benda tersebut terasa adanya pengaruh dari kesenian Cina dan Campa. Betapa pentingnya arca terakota adalah karena fungsinya selain sebagai hiasan bangunan juga sebagai dokumen visual budaya majapahit. ${ }^{21}$

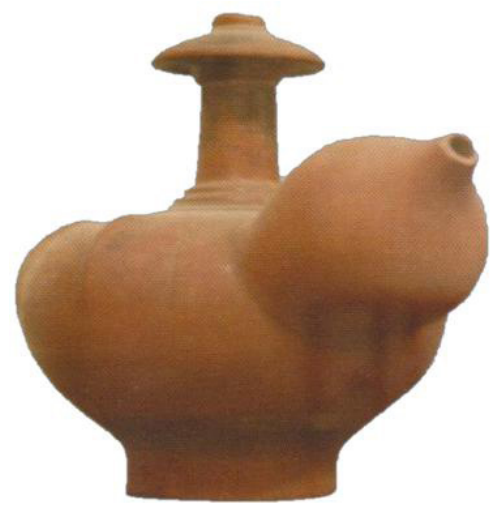

Gambar 7. Kendi dari Majapahit Repro: Prima Yustana dari Buku Keramik Untuk Hobi Dan Karir Pengarang Nia Gautama, Halaman 8

21. Prof. Dr. Mochtar Kusuma Atmaja dkk Perjalanan Seni Rupa Indonesia, KIAS Seni Budaya, 1991, Bandung, halaman, 40



Realisme baru dari boneka terakota ini menjelaskan perwujudan tokoh-tokoh yang pernah hadir di pusat kerajaan Majapahit. Boneka-boneka Majapahit berukuran kecil melukiskan potret dari tokoh-tokoh yang diperkirakan sebagai pembesar pemerintahan, pedagang, duta kerajaan, penari, penabuh gamelan di samping tokoh-tokoh dari cerita agama atau sosok kehidupan sehari-hari. Beberapa boneka yang berpenampilan seperti orang Cina dan Campa menunjukkan adanya hubungan kebudayaan Majapahit dengan kebudayaan luar. ${ }^{22}$



Gambar 9

Terakota Majapahit berbentuk kura-kura dari buku Majapahit Terracotta Art, Hilda

Soemantri Repro: Prima Yustana

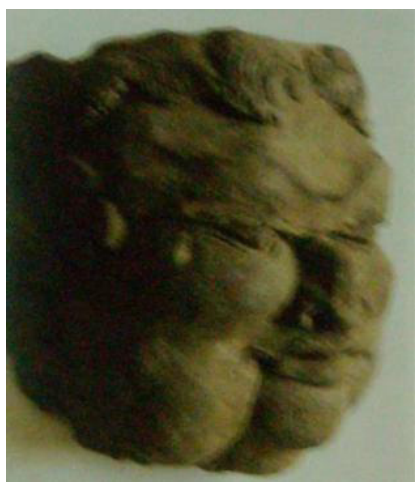

Gambar 10.

Terakota Majapahit berbentuk kepala manusia, dari buku Majapahit Terracotta Art, Hilda Soemantri diperkirakan sebagai wajah Patih GadjahMada Repro: Prima Yustana

22 Mochtar Kusuma Atmaja dkk., 1991, halaman 40 


\section{Ruang Lingkup Keramik}

Berbicara tentang ruang lingkup keramik maka dapat kita klasifikasikan ke dalam dua jenis, dalam hal ini adalah fungsional dan non fungsional atau hias. Keramik dalam kriteria fungsional lebih kepada fungsi praktis yang merupakan tujuan utamanya, seperti; mangkuk, gelas, piring serta berbagai bentuk yang lain yang difungsikan sebagai penunjang kehidupan manusia. Sedangkan keramik non fungsional dalam konteks ini adalah yang merupakan karya ekspresi seni bisa berbentuk patung keramik, atau karya seni keramik yang memiliki makna dan konsep penciptaan. Walaupun keramik dalam proses pencapaian pengakuan sebagai karya ekspresi melalui berbagai tahap, berawal dari hasil-hasil dari penciptaan perajin Cina, Korea dan Jepang adalah benda seni yang bergaris dinamis dan menyenangkan. Benda yang sangat menggembirakan bagi mata dan sentuhan ini tetap digunakan sehari-hari. Pikiran mengenai estetika yang dinamis ini sangat berbeda dari estetika benda seni Yunani kuno yang diperhitungkan dan direncanakan dengan teliti. $^{23}$

Pola pikir estetika timur menjadi sumber inspirasi bagi seniman keramik di seluruh dunia sejak pikiran estetis ini diperkenalkan ke dunia barat oleh Bernard Leach pada tahun tigapuluhan, tetapi bagaimanapun hasil karya keramik yang dinamis dan indah ini tetap dikatakan hasil "kerajinan", baru pada akhir tahun limapuluhan beberapa seniman Amerika, melalui karya keramiknya, menimbulkan kesadaran aneka ragamnya kemungkinan yang ada pada tanah liat sebagai bahan dasar karya seni rupa. Sepanjang sejarah memang ada patung persembahan, ubin keramik dan hiasan atap dibuat dari tanah liat yang membuktikan bahwa bahan ini telah dipakai untuk tujuan selain daripada hanya merupakan bahan produksi alat rumah tangga yang praktis. Tetapi objek keramik ini tidak pernah diakui sebagai medium untuk

23 Hildawati Siddhartha, Seni Keramik Modern, KIAS Seni Budaya, 1991, Bandung, halaman, 155 menyampaikan ekspresi pribadi. Penggunaan tanah liat sebagai alat untuk mengungkapkan ekspresi pribadi adalah suatu hal yang baru dalam dunia keramik. ${ }^{24}$

Saat ini ekspresi seni menggunakan medium keramik sudah sering kita temui, dan keberadaannya dapat diterima sebagai sebuah karya seni ekspresi dengan mengusung konsep tertentu. Keramik menurut sebagian orang kadang-kadang masuk ke dalam jenis karya seni patung, pendapat tersebut tidaklah salah, sebab seni keramik mempunyai beberapa jenis produk yang saat ini dapat dijadikan media berekspresi seni baik jenis karya patung maupun karya fungsional, seniman dapat bebas mengolah tergantung dari tema yang akan diangkat dan menggunakan jenis yang mana akan divisualisasikan, bahkan saat ini karya keramik juga sudah lazim digunakan sebagai karya instalasi.

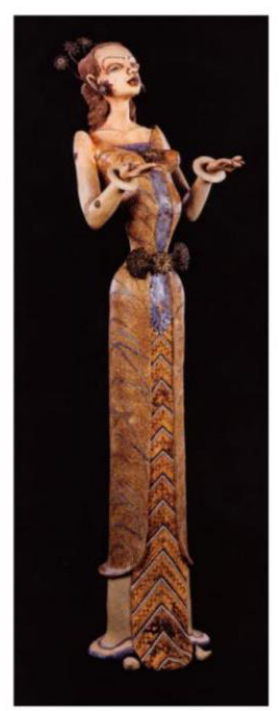

Gambar 11

Karya keramikus $\mathrm{F}$

Widayanto yang berupa patung Seri Dewi Sri Foto: Repro Prima Yustana dari buku Mengenal Seni Keramik Modern Nurdian Ichsan, halaman 69

Gambar 12. Karya salah satu seniman k e r a ik N e w Zealand Chris Weaver berbentuk teko kombinasi dengan gagang kayu

Repro: Prima Yustana, dari katalog portage ceramic awards

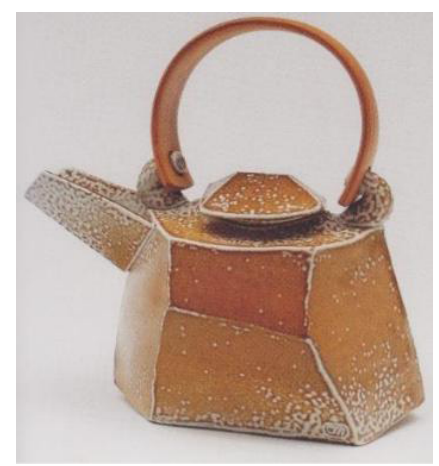

24. Hildawati Siddhartha, 1991, halaman 155 
Menurut Ambar Astuti industri keramik sebenarnya sangatlah luas; tidak hanya terbatas pada genteng, bata dan barang pecah belah saja. Seperti dapat dilihat sekarang, mulai dari alatalat listrik, peralatan laboraturium, kendaraankendaraan bermotor, pesawat terbang sampai ke pesawat angkasa luar, tempat-tempat pengecoran logam, beliau juga membagi menjadi beberapa kriteria keramik, yaitu:

a. Keramik Putih / keramik halus Barang keramik ini memang berwarna putih maka jenis ini dikenal sebagai barang putih (White Ware), yang sebagian besar merupakan barangbarang pecah belah misalnya cangkir, piring, dan termasuk barang saniter, alat laboratorium, isolator listrik.

b. Bahan-bahan bangunan dari tanah Yang tergolong disini adalah barang-barang yang dibuat dari bahan tunggal tanah liat dan yang dipakai sebagai bahan bangunan misalnya bata, genteng, pipa, tegel, alat-alat konstruksi dalam industri kimia dan sebagainya.

c. Gelas,

Barang ini dihasilkan dengan pembakaran bahan mentahnya sehingga cair, kemudian dalam keadaan setengah kental dituangkan ke dalam cetakan, kekerasannya dicapai karena didinginkan kembali. Karena bahan dari gelas ini adalah bahan silikat dan proses pembuatannya melalui peleburan pada suhu tinggi maka industri gelaspun termasuk keramik. Disamping menghasilkan barangbarang keperluan rumah tangga, industri gelas ini juga membuat barang-barang untuk keperluan laboraturium, bangunan dan kendaraan.

\section{d. Email.}

Yang dimaksud dengan barang-barang email ialah barang-barang logam yang permukaannya dilapis dengan selaput tipis dari sejenis gelas yang dilebur pada logam. Jadi barang email ini sesungguhnya adalah perkawinan antara keramik dan logam. Barang-barang email ini banyak dipakai dalam kehidupan sehari-hari terutama untuk keperluan rumah tangga seperti panci-panci, pecah belah dan lain sebagainya.

\section{e.Bahan-bahan perekat mortel}

Bahan-bahan ini adalah kapur, semen dan gips yang dibuat dari bahan pokok tanah/batuan dan yang proses pembuatannya memerlukan pembakaran pada suhu tinggi, oleh karena itu bahan-bahan ini digolongkan sebagai hasil keramik. Kapur dan semen merupakan bahan vital dalam dunia bangunan. Sedang gips dapat dipergunakan untuk bahan pencetak modelmodel, patung dan lain-lain. Benda-benda yang dibuat dari semen atau gips seperti balokbalok beton dan sebagainya bukanlah hasil keramik tetapi semen yang dipergunakan untuk membuat balok-balok itulah yang termasuk hasil keramik.

Keterangan di atas menunjukkan bagaimana luasnya ilmu keramik mulai dari peralatan rumah tangga sampai kepada produk-produk modern yang terdapat pada pesawat luar angkasa dan bahkan sekarang sampai kepada produk-produk yang berteknologi tinggi seperti jam tangan, pisau serta alat-alat yang berhubungan dengan kelistrikan.

\section{Jenis Keramik}

Pemahaman orang terhadap jenis keramik ada kemungkinan terjadi beberapa pemahaman yang berbeda satu sama lain, melalui tulisan ini penulis mencoba untuk memberikan gambaran menurut para ahli tetang jenis keramik dan apa saja yang membedakan serta karakteristik perbedaannya.

RA. Razak membedakan barang keramik menjadi dua golongan besar, yaitu barang yang tidak menghisap air dan barang yang menghisap air.

a. Barang yang tidak menghisap air Barangbarang yang tidak menghisap air terdiri dari golongan porselen dan golongan gerabah keras (stoneware). Barang-barang tersebut 
dibuat dari tanah putih (kaolin) dicampur dengan kwarsa, batu kapur (limestone) dan felspat kemudian dibakar sampai $\pm 1.400^{\circ} \mathrm{C}$. Bahan-bahan untuk barang porselen harus bersih dan tidak mengandung unsur besi dan sebagainya, supaya barang-barang tersebut kelihatan putih dan bersih. Lain halnya dengan barang-barang dari golongan gerabah keras, yang boleh berwarna asal tidak menghisap air.

\section{b. Barang yang menghisap air}

Barang-barang yang menghisap air terdiri dari golongan gerabah yang lunak (baik putih maupun merah) dan golongan barangbarang untuk bahan bangunan, seperti batu bata, genteng, ubin merah, pipa tanah, dan sebagainya. Selain itu ada lagi barangbarang yang tahan api seperti bata tahan api, semen tahan api. Barang-barang yang menghisap air dari golongan gerabah yang lunak, terdiri dari bahan kaolin, tanah liat dan kwarsa, hanya suhu pembakarannya yang lebih rendah daripada porselen, yaitu antara 900 dan $1.200^{\circ} \mathrm{C}$. Bahan-bahan untuk barang-barang bangunan dibuat dari tanah merah yang liat dan pasir atau semen merah dengan membakarnya sampai suhu antara $900-1.000^{\circ} \mathrm{C} .{ }^{25}$

\section{Jenis tanah liat atau macam body tanah liat}

Nia Gautama memberikan penjelasan tentang tanah liat, tanah liat yang telah dibakar dikategorikan sesuai dengan densitas bakarnya, yaitu earthenware, stoneware, dan porcelain. Earthenware memiliki suhu bakar paling tinggi sekitar $900^{\circ} \mathrm{C}$ dan hasilnya disebut gerabah atau tembikar dan terakota (terracotta, latin), tembikar identik berupa wadah, pot, dan perangkat makan, sedangkan terakota adalah yang bukan pot yaitu berupa patung dan relief. Tanah ini biasanya berwarna kemerahan setelah

25. R.A.Razak, Industri Keramik, PN Balai Pustaka, Media Wiyata, Semarang, 1992, halaman 21 dibakar. Jenis tanah ini biasanya tidak bergelasir dan tidak dapat menyimpan air dalam waktu yang lama, karena masih bisa menyerap air sekitar $10-15 \%{ }^{26}$

Stoneware, Tanah liat jenis stoneware pembakarannya bisa mencapai $1250^{\circ} \mathrm{C}$, sehingga tidak mudah ditembus oleh air, penyerapannya sekitar 2-5\%, apalagi kalau dilapisi gelasir, karena fungsi gelasir selain sebagai elemen dekorasi, juga untuk melapisi badan dari keramik itu sendiri. Jenis tanah liat stoneware inilah yang lebih banyak digunakan dalam dunia industri rumah tangga dan manufaktur. Porcelain, atau porselen berasal dari kata ,porcellno ${ }^{\text {ce }}$ yang diperkenalkan oleh Marcopolo pada abad ke13, yang berarti benda putih tembus pandang seperti kerang. Menurut Susan Peterson bahwa China mulai mengenal porselen sekitar 1000SM, dan porselen berkembang sangat baik di China dibandingkan dengan Jepang dan Korea. ${ }^{27}$

Porselen sangat tidak plastis, tetapi paling keras dan daya serap airnya hanya $0-1 \%$. Porselen berwarna putih dan bisa tembus cahaya jika tipis, tetapi semakin diberi warna, semakin berkurang daya tembus cahayanya, dan temperaturnya adalah yang paling tinggi yaitu sekitar $1300^{\circ} \mathrm{C}$. Bahan dasar porselen adalah kaolin, feldspar, dan silica. Karena sangat tidak plastis, maka porselen paling sulit dibentuk, dan hanya yang sudah sangat terampil bisa membuat benda-benda dengan teknik putar dari bahan ini. ${ }^{28}$ Tiga klasifikasi tersebut merupakan karakter utama dari bodi keramik yang sering kita ketahui, walaupun ada kombinasi tanah liat dengan bahan lain yang dapat juga digunakan untuk pembentukan bodi keramik seperti raku dan papperclay.

Terracotta, adalah badan tanah liat merah juga, nama terrcotta berasal dari Italia yang berarti "tanah bakaran" dengan penambahan pasir, atau grog (tepung tanah liat bakar, badan ini dapat dibakar sampai suhu

26. Nia Gautama, Keramik Untuk Hobi Dan Karir, Gramedia Pustaka Utama, Jakarta, 2011, halaman 17

27. Nia Gautama, Jakarta, 2011, halaman 18

28. Nia Gautama, Jakarta, 2011, halaman, 19 
stoneware $\left(1200-1300^{\circ} \mathrm{C}\right)$. Badan ini sukar diputar, tetapi sangat baik untuk dipres atau dicetak langsung untuk barang besar.

Bone China, badan khusus dipersiapkan dengan ketipisan, transparansi, putih, halus dan kekuatannya yang merupakan ciri khusus badan ini. Kualitas ini dicapai karena kandungan bone atau tulang yang telah dikalsinir (dibakar pada suhu rendah kemudian digiling halus), yang bertindak sebagai flux (penurun suhu) pada badan, membuatnya melebur kepada substansi yang keras seperti gelas pada suhu lebih dari $1240^{\circ} \mathrm{C}$. Pembentukannya dapat dilakukan dengan cetak tuang atau diputar meski agak sulit karena sifat masanya yang kurang plastis, teknik pembakarannya biasanya dibakar biskuit terlebih dahulu sampai mencapai titik matangnya, baru dibakar gelasir dengan suhu antara $1040-1080^{\circ} \mathrm{C} .{ }^{29}$

Raku, adalah suatu jenis khusus dari barang atau badan keramik yang dikembangkan oleh seniman-seniman keramik di Jepang pada zaman dahulu. Badannya harus banyak mengandung pasir atau grog, karena harus tahan perbedaan suhu selama proses pembakaran. Dapat dibentuk dengan cara pembentukan dengan tangan maupun diputar. Suhu ratarata yang digunakan untuk membakar raku adalah antara $750-1000^{\circ} \mathrm{C}$, dan pada umumnya badannya masih porous. ${ }^{30}$

Penjelasan di atas menjelaskan tetang jenis badan tanah liat sehingga para seniman dapat memilih dan memilah untuk menggunakan yang mana. Pemilihan jenis badan ini sangat berpengaruh terhadap karakteristik karya yang akan dibuat, sehingga keterwakilan karakter tanah liat dan prosesnya dapat mewakili konsep yang diusung dari kehadiran sebuah karya seni. Suhu pembakaran juga merupakan sebuah komponen yang mesti diperhatikan sebab bahan baku tanah liat menurut jenisnya juga memiliki konsekuesi logis suhu bakar yang harus dicapai pula. Pembakaran juga merupakan

29. Ambar Astuti, 1997, halaman 4-5

30. Ambar Astuti,1997, halaman 5 faktor penentu utama tingkat keberhasilan sebuah penciptaan karya seni, dari pembakaran yang baik maka akan muncul karya seni yang baik pula. Pengetahuan tentang jenis tanah liat dan karakteristiknya ini menjadi penting sebab klasifikasi produk keramik mayoritas terdiri dari jenis yang di jelaskan di atas.

\section{Rekam Jejak Keramik Di Indonesia}

Indonesia merupakan negara yang terbentuk dari pulau, suku dan berbagai perbedaan bahasa maupun agama yang beragam, oleh sebab itu kekayaan budayanya sungguh luar biasa. Keberadaan Indonesia sebagai sebuah negara sudah diakui oleh dunia internasional, salah satu yang dapat digunakan sebagai bagian dari identitas bangsa adalah beragamnya kesenian yang dimiliki oleh Indonesia. Kesenian dan kreatifitas saat ini menjadi salah satu potensi yang dapat meningkatkan daya saing terhadap bangsa lain. Keramik menjadi potensi kesenian yang ada di Indonesia yang sudah cukup lama berada di Indonesia.

Keberadaan keramik cukup mudah ditemukan karena pada dasarnya barang atau benda keramik merupakan sebuah alat yang digunakan oleh manusia untuk menunjang kehidupannya sebagai alat bantu dalam kehidupan sehari-hari pada masa-masa yang lalu. Keramik di Indonesia tersebar di beberapa wilayah, salah satunya di kota Yogyakarta, tepatnya di daerah Kasongan, ada beberapa macam produk di daerah ini seperti kuali untuk memasak nasi, kendi untuk tempat minum, gentong untuk menyimpan air, pengaron untuk mencuci, cowek untuk membuat sambal, anglo untuk tempat api guna memasak. Bentukbentuk keramik tradisional tidak berubah secara turun temurun, bahkan sejak dahulu tidak ada perubahan. ${ }^{31}$

Produksi keramik pada masa lalu hanya merupakan kerajinan rumah tangga atau home industri yang dikerjakan oleh perempuan maupun laki-laki, akan tetapi perempuan banyak menghasilkan barang-barang keramik tersebut, karena tugas laki-laki adalah bertani, 
berdagang, dan mungkin menjadi buruh. Dalam memproduksi keramik pada mulanya hanya berupa peralatan rumah tangga, akan tetapi setelah itu ada juga produk berupa celengan. Celengan adalah tempat untuk menabung uang logam, pada jaman penjajahan Belanda maupun Jepang rakyat masih berada dalam kemiskinan sehingga memiliki uang logam koin sudah sangat berharga dan ditabung atau dimasukkan ke dalam celengan. Bentuk celengan bermacammacam ada yang berbentuk bulat, binatang atau pengantin. Pengembangan seni rupa di Indonesia bermula pada tahun 1947 ditandai dengan banyaknya organisasi seni lukis dan patung. ${ }^{32}$

Selanjutnya seni rupa tampak berkembang pada tahun 1950 berdiri akademi Seni Rupa Indonesai (ASRI) Yogyakarta. Adanya ASRI dengan Kasongan ada pengaruhnya, sebab seniman kemudian dekat dengan pengrajin untuk mengembangkan produk yang ada di Kasongan sehingga bentuk dapat ditingkatkan dan kadang celengan tidak lagi sebagai tempat menyimpan uang tetapi sudah menjadi benda hias. Kerajinan keramik di Kasongan saat ini berubah dari produk konsumsi menjadi benda hias akan tetapi bentuk utamanya tetap mengacu pada bentuk celengan, berbagai produk yang dibuat antara lain benbentuk kuda beban, kambing, sapi, gajah, naga, kura-kura, temanten, burung garuda. Coraknya tetap sama, hiasanya dengan menggunakan teknik tempel. ${ }^{33}$

Dalam buku Pola Hidup Dan Produk Kerajinan Keramik Kasongan Yogayakarta memberikan gambaran bahwa produknya terklasifikasi beberapa jenis antara lain:

a. Barang-barang gerabah untuk keperluan dapur.

Di antaranya adalah kuali, pengaron, kendil, dandang, kekep, di samping alat-alat

31. Gustami dkk. Pola Hidup dan Produk Kerajinan Keramik Kasongan Yogyakarta, Depdikbud, 1985. Halaman 21

$21-22$

32. Gustami, dkk. Depdikbud., 1985, halaman

33. Gustami, dkk. Depdikbud., 1985, halaman 23 untuk keperluan dapur terdapat pula produkproduk untuk keperluan makan antara lain, cowek, cuwo, kendi dan teko. Bentuknya masih tetap sederhana nampak tidak mengalami perubahan sebagaimana dikerjakan oleh orang tua pengrajin terdahulu.

\section{b. Produk bahan bangunan.}

Bahan-bahan bangunan terbuat dari keramik di antaranya: batu bata merah, genting, pipa (plempem) dan pipa lengkung ( gulu banyak) untuk kelengkapan saluran septic tank. Pengrajin bahan bangunan saat ini sudah sangat jarang, adapun pengrajin yang membuat bata merah umumnya hanya digunakan untuk pembuatan rumahnya sendiri dan biasanya juga dikerjakan dengan cara gotong royong khususnya pada waktu pembakaran.

\section{c. Barang- barang hias.}

Benda hias dari keramik sesungguhnya telah dikenal oleh masyarakat pengrajin cukup lama. Benda keramik yang sudah cukup berumur antara lain berbentuk mantenan, jika diklasifikasikan jenis keramik hias ini terdapat dua macam jenis, yaitu benda hias yag tidak mempunyai fungsi lain,

d. Barang-barang mainan.

Produk mainan keramik telah dikenal oleh pengrajin secara turun-temurun, misalnya alat bunyi-bunyian seperti katak, kemudian celengan dengan berbagai bentuk variasinya. Bentuk celengan tidak saja dibuat dengan diberi ornamen yang indah tetapi juga memunculkan desain-desain yang baru. ${ }^{34}$

Gambaran tentang kondisi keramik di Indonesia terkait dengan kondisi di luar Indonesia seperti, Jepang dan Eropa, kedua wilayah ini terjadi transformasi pola produksi pra-modern ke modern yang ditandai dengan individuasi pada artist craftman. Agak berbeda dengan Amerika dan Australia, sejarah keramik mereka muncul tanpa adanya tradisi pola produksi pramodern (kecuali tentu saja pada bangsa Indian dan Aborigin yang minoritas). Sementara di

34. Gustami, dkk. Depdikbud., 1985, halaman $123-124$ 
Indonesia, tradisi keramik pra-modern terputus saat modernitas di Indonesia tidak menciptakan ruang transformasi bagi pola produksi keramik pra-modern tersebut. Apa yang disebut seni keramik modern Indonesia muncul ketika Institut Teknologi Bandung (ITB) membuka studio keramik pada tahun 1963, enam tahun setelah jurusan seni rupa berdiri, Pelukis Eddie Kartasubarna dan Angkama Setiadipradja adalah pendirinya, setelah mereka belajar keramik satu tahun di Amerika. Tak diragukan lagi bahwa gagasan dan pembelajarannya menganut paham modern. Pemikiran Eddie Kartasubarna yang memandang bahwa hakikat keramik adalah benda pakai bagi kegunaan praktis, tampaknya merupakan pengaruh dari masa ia belajar keramik di Alfred University New York. Seperti yang diungkapkan Peter Dormer, Universitas ini merupakan salah satu pendukung gagasan Leach. Namun Hildawati Soemantri, karena kedua pelukis ini kurang mendalami keramik maka mereka kurang mendalami wilayah teknis, hal ini juga diperparah oleh fasilitas yang kurang. Pada tahun 1968 Rita Widagdo, pematung terkenal lulusan Jerman, memperkuat jajaran staf pengajar di studio keramik yang memperkenalkan pendekatan Bauhaus. Pada masa itu secara konseptual lempung didekati sebagai material yang bisa dicetak sebagai sebuah bentuk, dibandingkan sebagai massa yang di dalam dirinya memiliki potensi warna, tekstur, dan ekspresi yang kaya. ${ }^{35}$

Pada tahun 1960-an secara umum kondisi medan seni Indonesia, pada masa itu didominasi ideologi seni abstrak dan formalis. Dalam pendekatan tersebut ada dua kecenderungan utama. Pertama keramik statusnya sama dengan material lainnya, ia hanyalah medium dalam upaya menambah esensi bentuk. Bentuk karya umumnya terkesan solid dan masif dengan karakter glasir doff atau matt, cerminan bentuk dasar dan karakter esensial. Kedua, pencarian karakter khusus material keramik seperti

35 Nurdian Ichsan, Mengenal Seni Keramik Modern, PT Dunia Pustaka Jaya, Bandung, 2012, halaman. 64 retak, kasar, dan ringkih, sebagai upaya untuk mendapatkan kesan-kesan estetik visual yang khusus. Pada masa ini kecenderungan figuratif dan representasi piktorial hampir tidak bisa ditemui. Meski demikian, tampak sebagian kecenderungan wadah, namun dalam kerangka pencarian dan pengkombinasian bentuk. Herbert Read juga melihat praktik seni keramik sebagai sebuah bentuk pure art, juga paham formalisme yang jika dirunut merupakan turunan dari pemikiran Roger Fry dan Clive Bell yang melihat bagaimana Significant form dapat ditemui juga pada benda-benda keramik. Pemikiran Peter Voulkous dengan cepat dikonsumsi sebagai dasar bagi praktik seni keramik dalam institusi. Seni keramik modern di Indonesia dimotori oleh institusi pendidikan, namun kondisi seperti ini mengandung persoalan terutama dalam kaitannya dengan pemahaman dan apresiasi publik. Seperti yang disinyalir oleh pameran Apresiasi Keramik Kreatif di Galeri Soemardja, Juli 1996, bahwa hal ini telah menciptakan jarak luar biasa antara pemahaman publik terhadap kecenderungan seni keramik modern yang dimotori oleh institusi pendidikan seni rupa dengan pemahaman umum. Hal ini dapat dijelaskan karena tidak terjadinya transformasi basis produksi pra-modern ke modern dalam keramik tradisional menyebabkan citra produk keramik secara umum masih dikenal sebagai sebuah benda yang sangat terhubung erat dengan sifat komunal dalam masyarakat serta memiliki sifat anonimitas, sangat berbeda dengan prinsip seni modern yang menyadarkan pada aspek individualitas senimannya. ${ }^{36}$ Seni keramik adalah cabang seni rupa yang mengolah material keramik untuk membuat karya seni dari yang bersifat tradisional sampai kontemporer. Selain itu dibedakan pula kegiatan kriya keramik berdasarkan prinsip fungsionalitas dan produksinya. ${ }^{37}$

36. Nurdian Ichsan, Mengenal Seni Keramik Modern, PT. Dunia Pustaka Jaya, Jakarta, 2012, halaman 65

Khastrifah Insvandairy, Karya Seni Bernilai Keindahan, 2009, Buana Cipta Pustaka, Jakarta Selatan, halaman 27 
KERAMIK KLASIK DAN KONTEMPORER

\section{Keramik Klasik}

\section{Pengertian dan ruang lingkup keramik} klasik

Definisi klasik sudah dibahas pada bab sebelumnya, bahwa klasik adalah bentuk ekspresi seni yang mencapai puncaknya pada periode kebudayaan Hindu dan Buddha (di Jawa dan Bali) dan Islam (di Sumatra, Jawa, Maluku). Secara khusus dalam penelitian ini keramik klasik akan merujuk pada pengertian tersebut, sehingga akan jelas batasan keramik klasik yang ada di Indonesia. Teknologi pembuatan pada keramik klasik akan terlihat pada wujud serta dekorasi yang ada pada badan keramik tersebut. Pada umumnya keramik klasik jarang memiliki lapisan glasir pada permukaan badannya walaupun tidak menutup kemungkinan ada yang memiliki lapisan glasir pada permukaan badannya.

Teknik dekorasi keramik klasik pada dasarnya memiliki karakteristik yang mirip dengan keramik kontemporer sebab pada keramik klasik teknik pembentukan dan dekorasinya juga masih sama dengan keramik kontemporer. Dekorasi keramik klasik juga mengenal istilah teknik gores, cukil, ukir ataupun dengan alat bantu, seperti kuas, butsir maupun alat sederhana yang dibuat oleh seniman pembuatnya. Keramik klasik biasanya mempunyai nuansa warna satu warna, namun walaupun hanya satu warna tidak mengurangi keindahan bentuknya, justru kadang menambah nuansa klasik dan elegan dari sebuah karya keramik.

Perspektif kebudayaan klasik seni harus dipandang sebagai bagian dari masalah keindahan. Seni rupa adalah tiruan dari apa yang tersirat, melewati batas jangkauan indrawi, dan menunjukkan keindahan spiritual sehingga seni tidak terbatas pada peniruan yang lahiriah saja. Praxis dalam pengertian seni rupa berarti kemampuan menerjemahkan yang tidak nampak menjadi nampak. Seni rupa pada kebudayaan klasik adalah: tiruan, tiruan kenyataan fisikal dan spiritual dari objek seni (manusia,alam), Tiruan dari sifat-sifat baik, unggul dan indah dari aspek spiritual objek seni. ${ }^{38}$

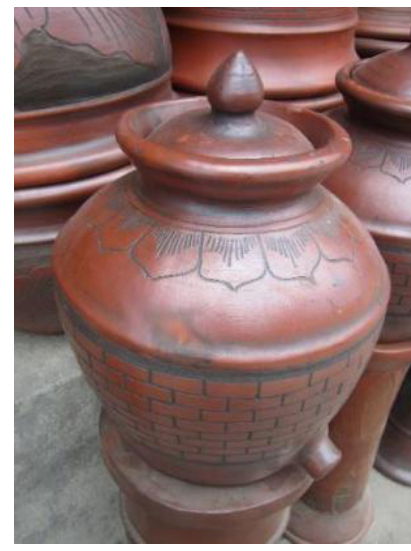

Gambar 13.

Padasan (wadah tempat air untuk berwudlu)

Foto: Prima

Yustana, lokasi

Bayat, Klaten

\section{Bentuk dan fungsi keramik klasik}

Pada masa perundagian, kerajinan gerabah (keramik bakaran rendah) mulai berkembang tidak hanya berupa alat rumah tangga melainkan mencakup berbagai alat perangkat sosial, ritual keagamaan, hingga ekspresi seni hiasan. Banyaknya temuan artefak di Trowulan sebagai tempat dimana kerajaan Majapahit berada, banyak ditemukan artefak seperti gerabah untuk keperluan ritual, seperti pedupaan, tempat sesaji, dan benda hiasan seni dan status sosial. Seniman - seniman pada masa inilah yang telah mengembangkan teknik dasar cukil, tusuk, gores, tempel dan tekan sebagai bentuk pengembangan teknik pembentukan dengan meja putar pada masa sebelumnya. ${ }^{39}$

Kerajinan gerabah tersebar hampir di seluruh wilayah Indonesia, hal ini terjadi karena munculnya kerajinan gerabah biasanya berada di sekitar pusat - pusat kerajaan di seluruh wilayah nusantara pada saat itu. Daerah yang memiliki sentra gerabah seperti: Banten, Panjunan Cirebon, Plered Purwakarta, Klampok Banjarnegara, Slawi Tegal, Mayong Jepara, Pagerjurang Klaten, Kasongan dan Jetis

38 Widagdo, desain dan kebudayaan, Penerbit ITB, Bandung, 2005, halaman 84.

39 M. Rosyid Kusnan, Aneka Gerabah, Saka Mitra Kompetensi, Klaten, 2018, halaman 1 
Pundong Yogyakarta, Malo Bojonegoro, dan Lombok Nusatenggara Barat. Kemungkinan masih ada wilayah lain yang belum disebutkan yang ada sentra kerajinan gerabah di Indonesia baik tradisional maupun kontemporer. ${ }^{40}$

Artefak pada masa kerajaan Majapahit sangat besar pengaruhnya terhadap berbagai jawaban atas berbagai pertanyaan yang terkait dengan keramik masa lalu baik bentuk dan fungsinya, di atas sudah sedikit tergambar bahwa fungsi keramik klasik pada masa lalu memiliki banyak fungsi, tidak hanya untuk alat bantu dalam kebutuhan rumah tangga, akan tetapi juga berfungsi sebagai alat penunjang kegiatan ritual keagamaan, hiasan sebuah bangunan, bahan bangunan, pipa saluran air, bahkan bangunan itu sendiri, dan sampai kepada alat permainan anak-anak seperti boneka atau bentuk peralatan permainan yang lain.
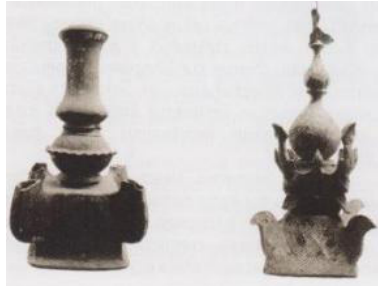

Gambar:14

Mustoko Masjid

Repro dari buku seni awang-awang

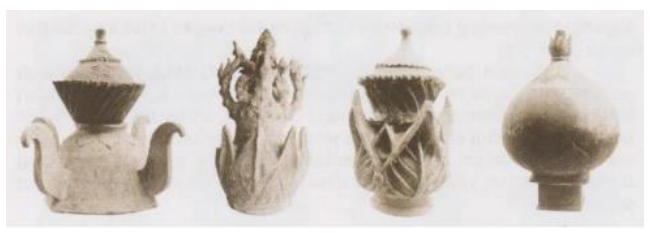

Gambar: 15

Berbagai jenis mustoko masjid Repro dari buku seni awang-awang

Gambar di atas menunjukkan sebuah benda keramik yang difungsikan sebagai sebuah hiasan bangunan, orang sering menyebutnya sebagai mustaka. Kata mustaka berarti kepala dalam bahasa Jawa krama inggil atau bahasa jawa yang halus, dalam hal ini karena menyangkut soal seni arsitektur maka mustaka yang dimaksud adalah mustaka dari

40 M. Rosyid Kusnan, 2018, halaman 2 sebuah masjid, yang artinya juga sebagai bagian kepala dari bangunan masjid tersebut. Mustaka masjid berada di puncak atap masjid, bentuknya biasanya bulat meruncing ke atas, atau persegi di bawah kemudian meruncing ke atas, pada puncaknya ada gambaran bulan sabit. Bentuk mustaka masjid yang demikian ini sebenarnya termasuk bentuk baru di Jawa, karena sebelumnya mustaka-mustaka masjid yang berada di Pulau Jawa biasanya mencontoh bentuk mustaka dari masjid Demak. ${ }^{41}$

Gambar mustaka di atas menunjukkan fungsinya sebagai bagian dari sebuah bangunan masjid, bentuknya menstilir tumbuh-tumbuhan menjadi simbol ukiran, Mustaka Terakota ini biasanya bersusun dua atau tiga yang masingmasing bagiannya dapat dilepas. ${ }^{42}$

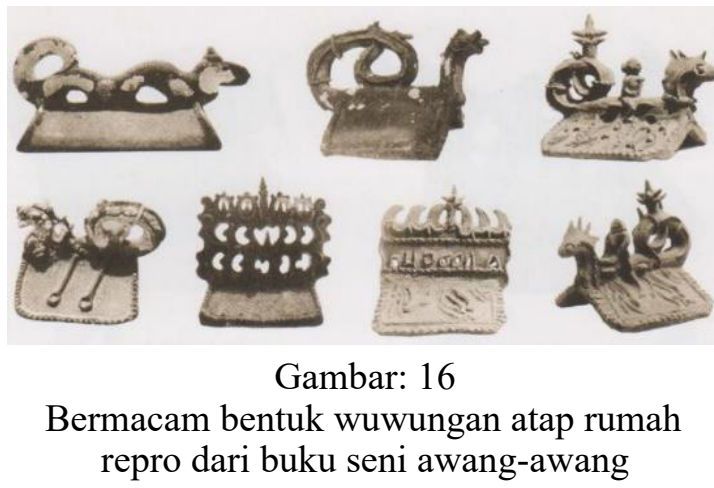

Pada gambar 16 menunjukkan bentuk dan fungsi keramik sebagai bagian dari bangunan, bentuk tersebut dinamakan wuwungan, Wuwungan berasal dari kata wuwung, yaitu bagian atas dari atap rumah tradisional di Jawa. Wuwungan berfungsi sebagai tutup pada atap rumah agar tidak ada air hujan ataupun debu yang masuk lewat atap. Wuwungan ini diletakkan pada genting teratas yang menempel pada kayu blandar mendatar yang disebut sebagai penuwun, yaitu balok kayu di bagian teratas dari sebuah atap rumah. Secara keseluruhan wuwungan ada dua jenis menurut bahan dasarnya, yang pertama wuwungan dari terakota dan kedua dari bahan logam/seng.

41 Hermanu, Seni Awang-Awang Arsitektur Jawa Lama, Bentara Budaya Yogyakarta, 2004, halaman 13

42 Hermanu, 2004, halaman 16-17 
Wuwungan dari terakota bentuknya segitiga datar tinggi sekitar $30 \mathrm{~cm}$ dan lebar $30 \mathrm{~cm}$, sedangkan yang dari seng lebarnya $30 \mathrm{~cm}$ panjangnya sepanjang wuwungan dari atap rumah itu sendiri. ${ }^{43}$

Wuwungan terakota ternyata berkembang pada beberapa wilayah seperti di daerah Pajangan, Bantul dengan bentuk seperti seekor naga yang distilir sedemikian rupa sehingga menjadi sebuah naga yang naif.

Wuwungan daerah Kulonprogo, wuwungan Kulonprogo berbentuk pipih tidak tiga dimensi, terdiri dari tiga jenis, yang pertama berbentuk naga, kedua berbentuk burung dan yang ketiga berbentuk seperti gunungan wayang. Sleman, adalah masuk wilayah Yogyakarta, wuwungannya mirip dengan yang terdapat di Kulonprogo, namun pada bagian tengahnya saja yang berbeda, bentuk gunungan sudah sangat disederhanakan sehingga tinggal menjadi semacam ornamen saja, namun bentuk burung pada bagian puncak masih kelihatan. ${ }^{44}$

Boyolali, wuwungan daerah ini berbentuk berbagai binatang dan manusia, ciri khas wuwungan Boyolali adalah dibuat utuh dan ada yang bisa dilepas atau pasangan. Yang bisa dilepas biasanya berbentuk patung monyet, anjing, ayam, harimau dan burung merpati, kemudian yang terusan berbentuk ukel, gelung wayang dan naga. Mayong Jepara, perlu diketahui bahwa daerah Demak dan Kudus pada masa lalu merupakan pusat kerajaan Islam di Jawa jadi di daerah ini tidak diperkenankan memasang hiasan yang berbentuk binatang atau manusia, kalau tumbuhtumbuhan diperkenankan, maka muncullah hiasan ukel-ukelan tersebut. Pati juga memiliki bentuk khas wuwungannya sendiri kebanyakan bentuknya berupa burung dan ayam, bentuknya dibuat terusan, cukup besar dan berat. ${ }^{45}$

43. Hermanu, 2004, halaman 17.

44 Hermanu, 2004, halaman 24.

45 Hermanu, 2004, halaman 29.

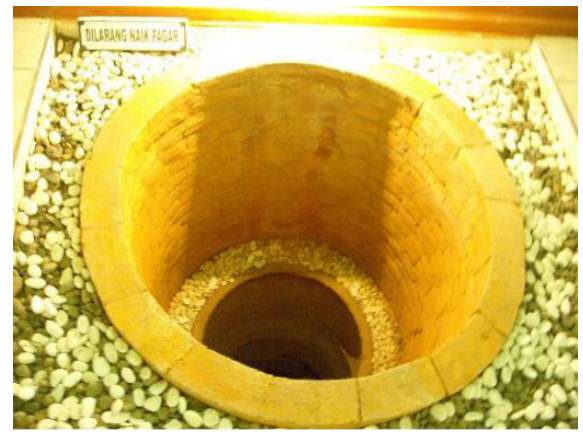

Gambar : 17

Keramik sebagai bahan bangunan Foto: Prima Yustana, lokasi Museum Trowulan

Gambar nomor 17 merupakan sebuah artefak keramik yang terdapat di daerah Trowulan, visual gambar menunjukkan bahwa keramik tersebut merupakan batu bata yang tersususun melingkar secara berurutan yang difungsikan sebagai penahan dinding tanah agar tidak longsor. Artefak ini biasa disebut sumur, sebagai tempat untuk menampung air dari mata air di bawah tanah. Secara benda fungsi batu bata adalah sebagai komponen utama pembuat bangunan, apabila diamati secara detail, artefak ini memiliki keunikan sendiri, yaitu pada bentuk batu bata yang sudah dipikirkan tingkat kemiringan dan lengkungan dari sisi batu bata agar pada saat dipasang dapat menjadi bentuk lingkaran yang sempurna.



Gambar: 18

Kendi Keramik

Repro dari prosiding seminar nasional seni kriya. "Kriya: Kesinambungan Dan Perubahan"

Kendi merupakan benda yang masih bisa ditemukan sampai saat ini, walaupun kendi merupakan benda yang sudah ada sejak jaman Majapahit atau bahkan sebelumnya. 
Secara fungsi, kendi merupakan tempat atau wadah untuk menyimpan air minum, bentuknya sangat unik, memyerupai teko namun tidak ada pegangan yang menempel pada badannya, cara mengangkatnya dengan cara dipegang langsung pada leher kendi yang dibuat cukup besar dan kuat. Secara teknik kendi dibuat dengan teknik putar, dengan bentuk akhir yang beragam, biasanya perbedaan bentuk terjadi pada cucuk tempat keluarnya air, ada yang dibuat biasa maupun dibuat agak mengembung, pada leher kendi dan tutup juga demikian. Pada wilayah tertentu juga ada yang membuat kendi dengan jumlah lubang tempat keluarnya air jumlahnya lebih dari satu dan ada juga yang membuat kendi yang unik, biasanya cara memasukkan air dengan cara tutup kendi dibuka dan kemudian dimasukkan air melalui lubang tersebut, namun ada yang memasukkan air dari bawah kendi sehingga tutup di atas bersifat permanen, kendi ini sering disebut dengan kendi maling.

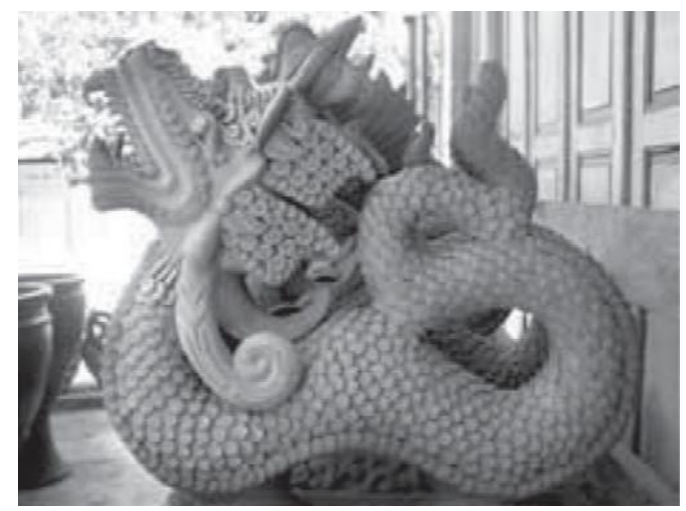

Patung Naga

Foto: Repro Prima Yustana dari buku Aneka Gerabah

Naga merupakan binatang yang sudah cukup lama dikenal pada kebudayaan manusia, binatang naga sebenarnya merupakan binatang fantasi yang berkembang sudah sejak lama, binatang ini sangat dekat dengan kebudayaan Tiongkok, sebab atribut budaya Tiongkok banyak memunculkan bentuk binatang naga ini, pada gambar nomor 19 di atas merupakan patung naga keramik yang banyak dibuat di daerah kasongan. Bentuk naga di kebudayaan Jawa juga sudah muncul, hal ini juga tampak pada benda-benda yang terdapat pada masa kerajaan. Dalam koteks karya keramik yang berbentuk naga seperti gambar di atas, secara teknik pembuatan menggunakan teknik campuran, baik pembentukan dengan tangan maupun menggunakan teknik tempel dalam pembuatan ornamen pada badan naga. Fungsi dari patung naga tersebut adalah untuk hiasan bangunan rumah.

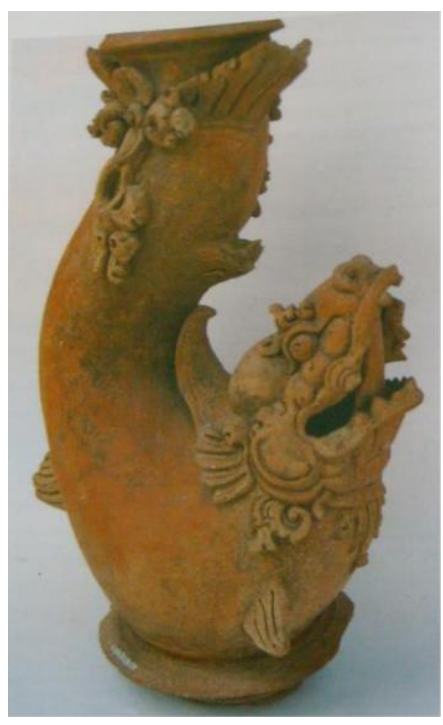

Gambar : 20

Dekorasi Pilar, Koleksi Museum Trowulan Repro: Prima Yustana, dari buku Majapahit Teracotta Art, Hilda Soemantri, Halaman 30.
Sebuah artefak keramik yang ada pada masa Majapahit, bentuknya antara dekoratif dan realistik. Bentuk dasarnya adalah ikan yang dibuat sangat artistik dengan ekor menjulang keatas dan bentuk kepala serta ekor dan sirip dengan bentuk dekoratif. Bentuk ikan ini sangat populer pada cerita Sri Tanjung yang banyak berhubungan dengan dunia roh dalam kehidupan dan kematian.

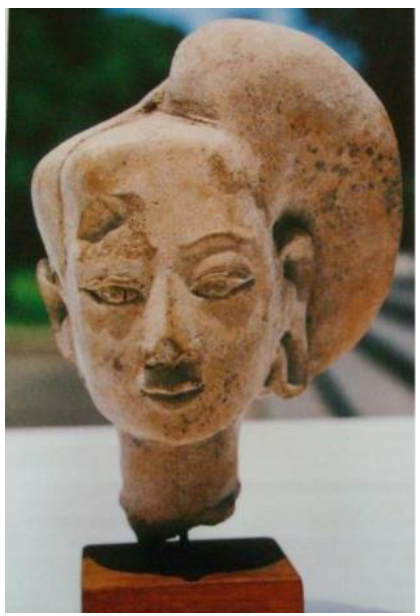

Gambar : 21

Patung Kepala

Wanita, Koleksi

Museum Keramik

Jakarta

Repro: Prima

Yustana, dari buku

Majapahit Teracotta

Art, Hilda

Soemantri,

Halaman 34. 
Patung kepala wanita yang diasumsikan sebagai wanita pada masa kerajaan Majapahit dan figur-figur tersebut biasanya berada di tempat suci, seperti yang terdapat di Pura Maospati dan Pura Tamansari. Figur patung wanita tersebut ditempatkan di luar candi sehingga kehilangan fungsi sebagai penjaga kuil sebab secara bentuk kehilangan kebesaran dari Majapahit. Wujud patung keramik ini sangat menarik dari segi bentuknya, sebab dari patung ini dapat kita ketahui pola kehidupan manusia khususnya wanita pada masa lalu, seperti gaya rambut bagaimana penampilan wajah dan bentuk wanita yang eksis pada masa Majapahit. Teknik pembuatan dan keterampilan seniman pada saat itu sangat menarik dengan memiliki kemampuan untuk membuat patung dengan cukup detail dan indah.



Gambar : 22

Gapura Wringin Lawang Masa Majapahit Repro Prima Yustana dari Buku

"Mengenal Kepurbakalaan Majapahit Di Daerah Trowulan"

Gapura Wringin Lawang terbuat dari bata, kecuali bagian anak tangganya yang terbuat dari batu, bentuk gapura adalah candi bentar (candi terbelah dua) dengan denah empat segi panjang berukuran panjang 13 meter,lebar 11,5 meter sementara tinggi bangunan 15,50 meter dan orientasi bangunan mengarah Timur-Barat dengan azimut 2790. Jarak antara dua bagian gapura selebar 3,5 meter dengan sisa-sisa anak tangga pada sisi timur dan barat. Diperkirakan anak tangga ini semula dibatasi oleh pipi tangga. Berdasar hasil penggalian arkeologis pada sebelah utara dan selatan gapura terdapat sisa struktur bata yang mungkin merupakan bagian dari tembok keliling. ${ }^{46}$ Penjelasan tersebut menggambarkan dengan jelas bahwa kerajaan Majapahit pada saat itu banyak menggunakan batu batu untuk membuat bangunan-bangunan, termasuk pada gapura Wringin Lawang yang sangat fenomenal yang diperkirakan sebagai gerbang masuk ke lingkungan kerajaan Majapahit saat itu.

\section{Ornamentasi keramik klasik}

Ornamen merupakan sebuah istilah yang sangat dekat dengan karya-karya kriya, secara istilah ornamen adalah satu-satunya seni visual yang tujuan utamanya adalah kesenangan. Ornamen secara fungsi dipadang terlalu berlebihan, nenek moyang kita tidak ada masalah dengan gagasan ornamen sebagai sebuah kesenangan, atau penerapannya dalam benda untuk menambah keindahan objek.

Ornamen adalah salah satu kategori seni yang mendasar seperti arsitektur, patung dan lukis. Itu adalah seni dengan sejarahnya sendiri, yang terdiri dari semua bentuk dan pola yang telah diterapkan manusia pada bangunan, perkakas, prabot, senjata dan benda-benda praktis, tekstil dan pakaian bahkan tubuh mereka sejak jaman prasejarah. Namun tidak seperti arsitek, patung dan lukis, ornamen tidak memiliki tempat yang diakui dalam perkembangan budaya saat ini. ${ }^{47}$

Ragam hias yang terdapat di dalam kesenian Jawa Hindu secara umum dapat digolongkan atas gambar-gambar anthropomorf gambar-gambar binatang, tumbuh-tumbuhan, dan pola-pola geometris. ${ }^{48}$ Ornamentasi keramik masa

46. I Made Kusuma Jaya dkk., Mengenal Kepurbakalaan Majapahit Di Daerah Trowulan, buku pegangan museum Trowulan

47 James Trilling, The language of Ornament, Thames and Hudson World Of Art, London, 2001, halaman 14

48. Van der Hoop dalamTimbul Haryono, Seni Pertunjukan dan Seni Rupa dalam perspektif Arkeologi Seni. ISI Press, Yogyakarta, 2007, halaman 100-101 
klasik juga sangat terkait dengan kebudayaan masa Hindu jadi kemungkinan besar ada sebuah relevansi terhadap kemunculan artefak keramik masa klasik yang ada.

Kekuatan visual dari keramik diantaranya: bentuk, tekstur, out line, warna glasir, warna tanah, ornamentasi dengan motif-motif yang sarat makna dan simbol, serta nilai lain yang sangat dekat dengan pandangan kita. ${ }^{49}$ Berdasarkan penjelasan tersebut bahwa terbentuknya ornamen dalam keramik tidak lepas dari bahan dasar pembentuknya, dalam hal ini adalah tanah liat yang dapat diterapkan berbagai sentuhan teknik terhadapnya sehingga terbentuklah bermacam karakter hias yang muncul pada permukaan badanya atau bahkan bentuk secara keseluruhan.

Berdasarkan artefak keramik klasik yang ada, secara visual terdapat beberapa catatan tentang bagaimana bentuk ornamentasinya, ornamen dalam keramik klasik terdapat dominasi warna natural tanah liat setelah proses pembakaran yang dapat menampilkan bermacam warna tingkat kematangan badan keramik yang muncul disebabkan pengaruh dari teknik pembakaran. Terbentuknya ornamen dalam keramik klasik melalui teknik putar, gores, pijit, tempel dan cetak.

\section{Keramik Kontemporer}

\section{Pengertian dan ruang lingkup keramik} kontemporer

Wilayah Fine Art kontemporer berpusat di sekitar galeri dan museum, aktifitas pameran yang diadakan di galeri dan museum menjadi sebuah indikator bahwa pameran tersebut dilakukan secara profesional dalam praktik seni Fine Art dan secara substansional menjadi kelengkapan dalam aktifitas kritik seni, teori, peliputan, artikel esai katalog, monograf dan buku. Seniman dan curator berada di tengah jalinan konteks teoritis. Otonomi seni menjadi salah satu arahan bagi para pekeramik, namun

49. Noor Sudiyati dalam Kriya Kesinambungan dan Perubahan, LPPSK, Yogyakarta, 2009, halaman 119. para seniman, kurator, dan pelaku lainnya dalam medan seni secara jelas tidak ingin melibatkan para pekerja yang menggunakan material lempung. Lempung banyak ditentang untuk diakui sebagai medium seni patung, dan kemungkinan pendapat tersebut dilatarbelakangi bahwa lempung dinilai hanya digunakan sebagai bahan pembuat giftware domestik, folk, rural dan para amatir. Tersirat lempung memiliki citra rendahan dan bukan intelektual. ${ }^{50}$

European Ceramics Work Centre atau EKWC menjadi penghubung antara pekeramik dengan dengan budaya senirupa kontemporer dengan cara melibatkan seniman-seniman yang diakui dalam fine art untuk bekerja dengan lempung. Tujuannnya adalah Pertama menghubungkan dunia keramik dengan dunia mainstream seni kontemporer dengan melibatkan ketertarikan seniman-seniman terhadap teknologi keramik dan mendorong pencapaian melalui medium keramik karena sebagian besar tidak mengetahui tentang lempung, tujuan kedua tidaklah bersifat praksis, namun lebih penting. Bahwa objek dan teknologi cara pembuatan objek membawa makna yang tidak bisa ditemukan dalam teori, sesuatu yang tidak bisa diwakili kata-kata, karena salah satu karakter dari seni kontemporer, baik bagi seniman maupun kurator adalah melihat artefak hanya sebagai pelengkap bagi label atau esai katalog yang menyertainnya. EKWC mempercayai pentingnya sebuah objek. Khususnya dalam keramik kontemporer hubungan antara objek dan maknanya dan antara objek dan kata-kata kadang-kadang sangat rumit dan kontradiktif dibandingkan yang tampak dalam "kenyataan" seni patung. Meskipun sering disebutkan bahwa fine art kontemporer bergantung pada muatan teori dan penjelasan tertulis atau verbal, demikian juga dalam kasus keramik saat ini yang juga tergantung pada bahasa sebagai sesuatu yang menunjukkan bagaimana pengertian langsung makna sebuah objek secara individual. $^{51}$

50 Nurdian Ichsan, Mengenal Seni Keramik Modern, PT Dunia Pustaka Jaya, Bandung, 2012, halaman 79

51. Nurdian Ichsan, 2012, hal. 81 
Kini banyak seniman yang dipengaruhi oleh lingkungan di sekeliling mereka dan dengan jelas menghasilkan karya bermuatan kritik sosial, lingkungan dan isu politik. Senada dengan itu Mutsuo Yanagihara salah satu juri dalam The World Ceramic Biennale Korea pada tahun 2005, menyatakan bahwa makin sulit memisahkan karya keramik dengan seni patung, tampak dari karya seni yang masuk merupakan kategori ekspresi. Keramik kontemporer menjadi wilayah baru seni patung dan merupakan sebuah pengalaman akan kebebasan masa kini. ${ }^{52}$

2. Bentuk dan fungsi keramik kontemporer

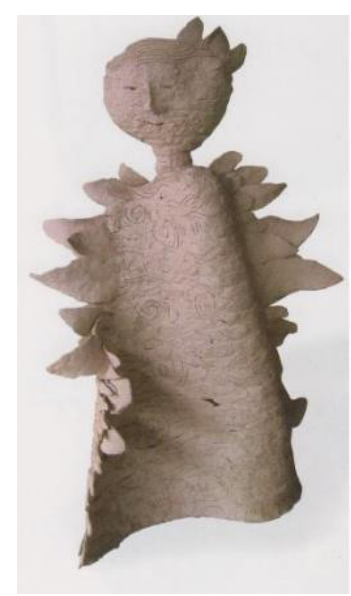

Gambar : 23

Keramik

Kontemporer karya

Noor Sudiyati dari buku prosiding jaringan makna halaman 248

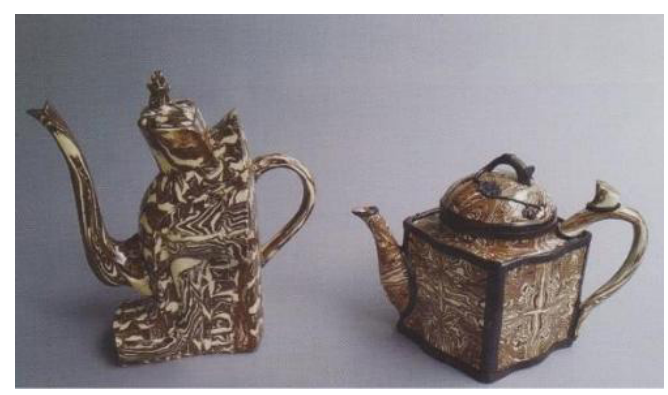

Gambar : 24

Karya Keramik Kontemporer dari New Zealand

52 Nurdian Ichsan, 2012, hal. 92
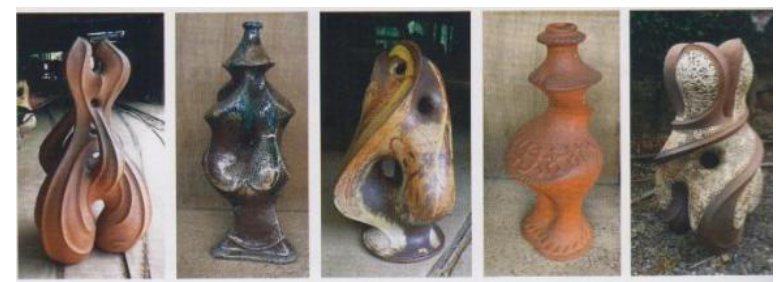

Gambar : 25

Keramik Kontemporer

Buku rails toward the sky Barry Brickell hlmn 194

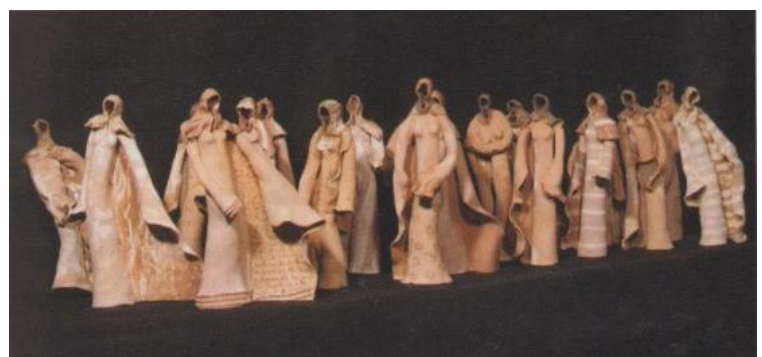

Gambar : 26

Karya Keramik Endang Lestari dari buku Keramik untuk Hobi dan Karir, Halaman 103



Gambar : 27

Karya Keramik Nia Gautama halaman 103

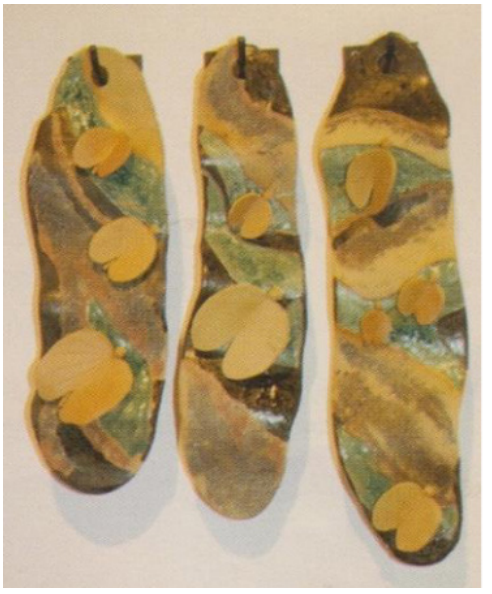

Gambar : 28

Karya Keramik Nia Gautama dari buku keramik untuk hobi dan karir

eramik untuk hobi dan karir

Gambar: 31 




Gambar : 29. Karya Keramik Nathas Setiabudi Repro dari buku Nia Gautama Keramik untuk hobi dan karir

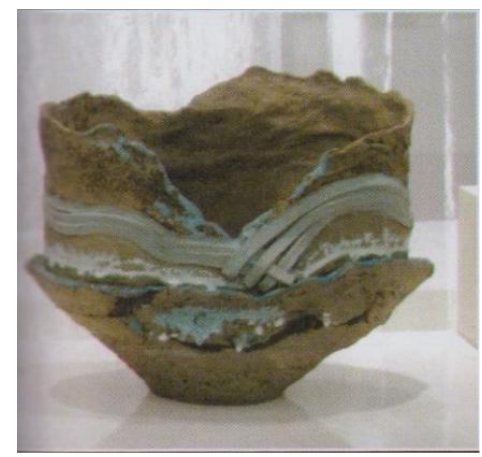

Gambar : 30. Keramik Karya Lydia Poetry Repro dari buku Nia Gautama Keramik untuk Hobi dan Karir



Gambar: 32 Karya Keramik Prima Yustana, Vas Bunga



Gambar: 31

Karya keramik Prima Yustana, judul: 2 Pilihan

\section{Ornamentasi keramik kontemporer}

Keramik kontemporer atau keramik masa kini merupakan sebuah fenomena yang sangat menarik untuk dikaji lebih dalam terkait keberadaannya di Indonesia, kajian dalam konteks ornamen dalam keramik kontemporer tentunya berbeda dengan melihat dan menganalisis terhadap karya seni yang lain misalnya oranamen logam, kayu bahkan kulit. Spesifikasi bahan dan proses aplikasi dalam mewujudkan sebuah motif hias yang meliputi badan keramik diperlukan tahapan khusus dengan teknik khusus, walaupun ada juga yang menggunakan teknik yang sederhana untuk memunculkan keindahan ornamen yang ada pada keramik kontemporer.

Jenis motif hias yang biasa muncul dalam keramik kontemporer sangat tergantung pada bentuk dan tujuannya, sebab sebagian besar artefak yang ada pada keramik kontemporer sebagian besar berupa sebuah karya seni yang bermakna dan lebih menekankan pada ekspresi dari pembuatnya. Ekspresi seorang seniman bersifat sangat individu sekali jadi biasanya ornamen yang muncul pada badan keramik juga sesuai ekspresi masing-masing senimannya. Beberapa ornamen hias yang sering muncul dalam keramik kontemporer adalah mayoritas permainan glasir sangat dominan dibanding 
yang mengandalkan kekuatan warna tanah. Ornamen keramik yang lain adalah dengan mengandalkan tekstur atau nilai raba dari sebuah karya keramik baik goresan maupun terbentuk tekstur dari proses dalam pembentukan keramik dengan menggunakan teknik pilin atau slab.

Catatan yang menjadi penting dalam keramik kontemporer adalah bentuk karya secara keseluruhan sudah membangun kekuatan hias dari sebuah karya keramik kontemporer, karya keramik kontemporer tidak semua berupa karya ekspresi, namun ada juga karyakarya fungsional yang yang dibuat kekinian yang banyak mengangkat ide-ide yang jarang diwujudkan dalam karya keramik. Karakteristik badan keramik menjadi sangat penting jika mengambil ide gagasan dari benda maupun alam sekitar, visualisasi oranamennya pasti akan mengacu pada detail karakteristik dari objek acuan atau dengan kata lain meniru karakter alamiah yang ada kemudian divisualisasikan dengan teknik yang ada dalam keramik seperti gores, ukir, maupun metode perwujudan dekorasi yang masih eksperimental.

\section{ESTETIKA KERAMIK KLASIK DAN KONTEMPORER}

\section{Estetika Keramik Klasik}

Gaya atau style merupakan sebuah kata yang patut dipertimbangkan juga dalam membaca sebuah karya keramik khususnya keramik klasik, sebab karya seni keramik klasik kriteriannya adalah yang muncul dibawah tahun 70 an, sedangkan sekarang atau pada saat ini juga sering ditemui karya keramik yang berbentuk seperti pada kriteria tersebut keramik klasik. Hal tersebut dapat terjadi, sebab ide gagasan dalam penciptaan sebuah karya seni sering juga mengambil ide atau gagasan dari karya-karya masa lampau bahkan ada juga yang sifatnya duplikasi ataupun revitalisasi, maka dalam memahami karya keramik klasik yang lahir pada saat ini harus dengan melihat dengan perspektif gaya yang mengikutinya.
Keramik klasik juga memiliki karakternya sendiri, Estetika timur juga lekat dengan estetika Jawa, ciri khususnya adalah: bersifat kontemplatif-transedental, bersifat simbolik, bersifat filosofis, kriteria tersebut menjadikan estetika keramik klasik, lebih dekat kepada bentuk-bentuk simbolik yang bisa jadi bersifat transeden. ${ }^{53}$ Berdasar keterangan tersebut sangat jelas bahwa keramik klasik dapat mewakili beberapa keadaan tersebut sehingga secara visual ada beberapa bagian yang dapat dikorelasikan dengan beberapa kriteria pada estetika jawa. Keindahan keramik klasik dengan demikian sangat tergantung bagaimana bentuk dan fungsinya sebagai apa pada masa lampau, sehingga keindahan dari sebuah keramik klasik sangat dipengaruhi dengan kontekstual situasi dan kondisi keramik tersebut difungsikan. Dalam melihat estetika keramik klasik dapat disesuaikan dengan artefak yang diamati apakah itu benda fungsional, Patung, benda hias, bahan bangunan, asesoris bangunan atau bahkan bangunan itu sendiri.

Keindahan keramik klasik sangat khas, hal ini muncul dari kekuatan utama tanah liat yang dibentuk menjadi sebuah benda apapun fungsinya, dari sebuah tanah liat yang tidak berbentuk menjadi berbentuk dan memiliki fungsi yang sangat beragam untuk menunjang berbagai kebutuhan manusia. Keindahan keramik klasik justru muncul karena fungsinya yang sangat luar biasa dan dapat menunjang kehidupan manusia bisa jadi hingga saat ini. Ada benda keramik klasik yang pada masa lampau sudah digunakan oleh manusia hingga saat ini masih bisa kita nikmati bentuk, keindahan, maupun fungsinya.

\section{Estetika Keramik Kontemporer}

Berbicara tentang keindahan keramik kontemporer ada beberapa cara pandang dalam menjelaskan estetika, menurut Monroe Beard sley menyatakan bahwa ada 3 unsur yang menjadi sifat-sifat membuat baik atau indah sesuatu karya estetik yang diciptakan oleh seniman.

Agus Sachari, 2002, halaman 12 
Ketiga unsur itu adalah: Pertama, kesatuan (unity) unsur ini berarti bahwa karya estetis itu tersusun secara baik atau sempurna bentuknya. Kedua Kerumitan (complexity) karya estetis itu tidak sederhana sekali, melainkan kaya dengan isi maupun unsur-unsur yang saling berlawanan atau mengandung perbedaanperbedaan yang halus, kalau tidak terdapat unsur kerumitan, maka sebidang tembok yang dicat putih yang menunjukkan kesatuan bisa dianggap sebagai benda yang indah. Padahal kenyataannya tidaklah demikian, jadi unsur kesatuan harus dilengkapi dengan unsur yang kedua sehingga menjadi kesatuan dalam keragaman. Ketiga, kesungguhan (intensity) suatu karya estetis yang baik harus memiliki suatu kualitas tertentu yang menonjol dan bukan sekedar sesuatu yang kosong. Tidak menjadi soal kualitas apa yang dikandungnya (misalnya suasana suram atau gembira, sifat lembut atau kasar), asalkan merupakan suatu benda yang sungguh-sungguh intensif. $^{54}$

Melihat penjelasan di atas ketika melihat sebuah karya seni keramik maka akan sangat terarah dengan melihat teori tersebut, secara sederhana apabila karya seni semua kriteria yang ada di dalamnya masuk dalam klasifikasi teori tersebut maka dengan mudah akan disebut sebagai karya seni yang indah. Namun untuk menilai estetika karya keramik kontemporer bisa terjadi beberapa perbedaan interpretasi apabila melihat karya-karya yang ada pada saat ini. Melihat keindahan keramik kontemporer saat ini bisa dimulai dengan melihat bentuk dan teknik pembuatannya, baik yang berglasir maupun yang tidak berglasir.

Estetika keramik kontemporer saat ini cukup beragam bentuk dan wujudnya, akan tetapi sebagian besar memiliki kekuatan konsep penciptaan yang sangat kuat, konsep penciptaan ini menjadi ruh dari sebuah artefak keramik kontemporer. Setelah konsep penciptaan baru dapat dilihat dari unsur bentuk atau wujud dari karya keramik kontemporer tersebut. Keindahan bagi seseorang tentunya akan sangat subyektif, namun biasanya keramik kontemporer memiliki keindahan dan karakternya sendiri. Keindahan keramik kontemporer berhubungan erat dengan makna yang dikandung dalam setiap karya.

${ }^{54}$ The Liang Gie, Filsafat keindahan, Pusat Belajar Ilmu Berguna (PUBIB) Yogyakarta, 2005, halaman 43.

\section{Kesimpulan}

Estetika Keramik Klasik Dan Kontemporer terdapat banyak struktur pembentuk keindahan dari masing-masing karya keramik, baik klasik maupun kontemporer. Metode pembentukan dalam karya keramik baik klasik maupun kontemporer mempunyai cara yang hampir sama, sebab sejarah keramik membuktikan bahwa metode penciptaan keramik secara manual tidak banyak mengalami perubahan yang berarti, kecuali keramik industri memang perkembangan teknologinya sudah cukup maju. Keindahan keramik dapat dilihat dengan melihat dari awal proses pembuatannya, proses dalam keramik sangat menentukan sisi keindahan dalam benda keramik. Estetika keramik klasik maupun kontemporer ditentukan dengan proses yang tepat dalam pembuatan keramik, tepat dalam keramik adalah sesuai dengan prosedur pembuatan, apabila sudah sesuai prosedur maka secara visual dapat terlihat pada wujud akhir karya keramiknya.

Perbedaan yang sangat mencolok terkait dengan estetika keramik klasik maupun kontemporer. Keindahan keramik klasik dapat dinikmati melalui bentuk-bentuk yang sangat menarik, mulai dari bangunan kerajaan seperti pada masa Majapahit, ataupun bentuk yang merupakan bagian dari elemen bangunan, seperti hiasan tiang ataupun wuwungan dan mustaka masjid, bentuk mainan berupa patung boneka maupun tempat untuk menyimpan koin. Keindahan keramik klasik juga muncul dari teknik gores maupun warna badan tanah yang jarang menggunakan glasir, tetapi melalui kekuatan goresan maupun warna tanah liat keramik klasik juga bisa tampil elegan, walaupun pada masa lampau diluar negeri sudah banyak keramik klasik yang berglasir. 
Keramik kontemporer saai ini banyak di warnai dengan karya-kaya konseptual yang merupakan ekspresi pribadi seniman, sehingga keindahan muncul dari kesatuan tema dan wujud visualnya. Makna sebuah karya juga menjadi bagian utuh dari sebuah karya keramik kontemporer. Keindahan visual dalam keramik kontemporer terlihat dengan banyaknya penggunaan lapisan glasir pada karya, walaupun ada juga karya keramik kontemporer yang tidak menggunakan lapisan glasir.

\section{Datar Pustaka}

Astuti, Ambar, Pengetahuan Keramik, 1997, Gadjah Mada Universty Press, Yogyakarta.

Dharsono (Sony Kartika), 2007, Estetika, Rekayasa Sains.

Gustami dkk. 1985, Pola Hidup dan Produk Kerajinan Keramik Kasongan Yogyakarta, Depdikbud.

Gie, The Liang, 2005, Filsafat keindahan, Pusat Belajar Ilmu Berguna (PUBIB) Yogyakarta.

Hermanu, 2004, Seni Awang-Awang Arsitektur Jawa Lama, Bentara Budaya Yogyakarta.

Insvandairy, Khastrifah, 2009, Karya Seni Bernilai Keindahan, , Buana Cipta

Pustaka, Jakarta Selatan.

Ichsan, Nurdian, 2012, Mengenal Seni Keramik Modern, PT Dunia Pustaka Jaya, Bandung.

Kusnan, M. Rosyid, 2018, Aneka Gerabah, Saka Mitra Kompetensi, Klaten.

Kusuma Jaya, I Made, dkk., Mengenal Kepurbakalaan Majapahit Di Daerah Trowulan, buku pegangan museum Trowulan
Kamus KBBI versi aplikasi android.

Kusuma Atmaja, Mochtar, dkk. 1991, Perjalanan Seni Rupa Indonesia, KIAS Seni Budaya, Bandung.

Razak, R.A., Industri Keramik, 1992, PN Balai Pustaka, Media Wiyata, Semarang.

Siddhartha,Hildawati, 1991, Seni Keramik Modern, KIAS Seni Budaya, Bandung.

Susanto, Mieke, 2018, Diksi Rupa, Dictiart Laboratory, Yogyakarta.

Sachari, Agus, 2002, Estetika Makna, Simbol dan Daya, Penerbit ITB.

Sudiyati, Noor, dalam Kriya

Kesinambungan dan Perubahan, LPPSK, Yogyakarta.

Trilling, James, 2001, The language of Ornament, Thames and Hudson World Of Art, London.

Van der Hoop dalamTimbul Haryono, 2007, Seni Pertunjukan dan Seni Rupa dalam perspektif Arkeologi Seni. ISI Press, Yogyakarta.

Widagdo, 2005, Desain Dan Kebudayaan, Penerbit ITB, Bandung.

Zulfikar, M. Yusuf Arkeologi, 2011, PT. Remaja Rosdakarya, Bandung. 